COLLEGE OF ENGINEERING

ENGINEERING EXPERIMENT STATION Box 3449/Las Cruces, New Mexico 88003

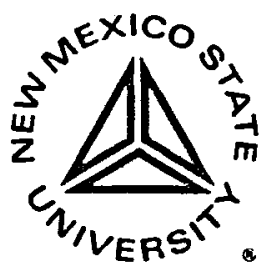

FINAL REPORT

\title{
Geothermal space Heating for the Senior Citizens Center at Truth or Consequences, New Mexico
}

DISCLAIMER

This book was preagared as an account of work sponsored by an agency of the United Stetes Government.

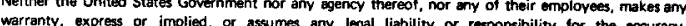

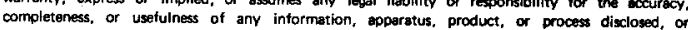

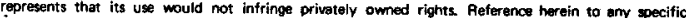

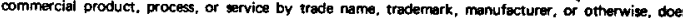
not necossarily constitute or imply its endorsement, recommendation, or ferworing by the Uniteo Staless Government or any agsency therefor. The views and opinions of muthors expressed heroin do not

necesssarily state or refiect those of the Unined States Government or any yesency theresot. by

T. R. Mancini

L. N. Chaturvedi

T. G. Gebhard

DOE/ID/01756--T2

DE82 014293

submitted to

The New Mexico Department of Energy and Minerals on Contract No. 67-52

The Four Corners Regional Commission

on Contract No. 492-127-063-2

The United states Department of Energy Division of Geothermal Energy

on Contract No. D-AS07-78IDO-1756 MOD 5

\section{March 1982}

$$
\text { 2. NOTICE - }
$$

PORTIOUS OF THIS REPQRT ARE ULLEGIBLE.

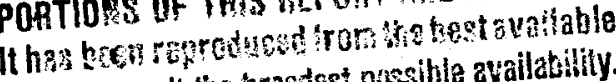
copy to permil the oragdest pussible availatility. 


\section{DISCLAIMER}

This report was prepared as an account of work sponsored by an agency of the United States Government. Neither the United States Government nor any agency Thereof, nor any of their employees, makes any warranty, express or implied, or assumes any legal liability or responsibility for the accuracy, completeness, or usefulness of any information, apparatus, product, or process disclosed, or represents that its use would not infringe privately owned rights. Reference herein to any specific commercial product, process, or service by trade name, trademark, manufacturer, or otherwise does not necessarily constitute or imply its endorsement, recommendation, or favoring by the United States Government or any agency thereof. The views and opinions of authors expressed herein do not necessarily state or reflect those of the United States Government or any agency thereof. 


\section{DISCLAIMER}

Portions of this document may be illegible in electronic image products. Images are produced from the best available original document. 
Geothermal space Heating for the Senior Citizens Center at Truth or Consequences, New Mexico

\section{ABSTTRACT}

A demonstration project to heat the Senior Citizens Center at Truth or Consequences, New Mexico with geothermal waters is desciribed in this report. The project was jointly funded in August of 1979 by the New Mexico Department of Energy and Minerals, the Four Corners Regional Commission, and the United States Department of Energy Division of Geothermal Energy.

There were three phases to the project:

Phase I - Design and Permitting

Phase II - Installation of the Heating System and Well Drilling

Phase III - Operation of the system

All three phases went well and there was only one major problem encountered in the project. This was that the well which was drilled to serve as the geothermal source was dry. This could not have been anticipated and we had, as a contingency plan, the option of using an existing sump in the Teen Center adjacent to the Senior Citizens Center as the geothermal source. The system was made operational in August of 1981 and has virtually supplied all of the heat to the Senior Citizens Center during this winter.

As a direct result of the project, Dr. Mancini contacted the Modine Manufacturing Company, Inc., the company which supplied the heating units, and they agreed to donate six more 
units to expand the system to heat the remainder of the building, the Teen and convention centers. The city is in the process of installing these systems at this time. 


\section{List of Figures}

Figure No.

Page No.

1 The Geology of $\mathrm{T}$ or $\mathrm{C} \ldots \ldots \ldots \ldots \ldots \ldots \ldots \ldots \ldots$

2 The Original Well site $\ldots \ldots \ldots \ldots \ldots \ldots \ldots \ldots 6$

$3 \quad$ Limestone $\ldots \ldots \ldots \ldots \ldots \ldots \ldots \ldots \ldots \ldots \ldots \ldots \ldots$

4 Temperature Log of Dry Well $\ldots \ldots \ldots \ldots \ldots \ldots .7$

5 Temperature-time Log of Teen Center Well ..... 9

6 Well Locations $\ldots \ldots \ldots \ldots \ldots \ldots \ldots \ldots \ldots \ldots . \ldots$

7 Teen Center Sump $\ldots \ldots \ldots \ldots \ldots \ldots \ldots \ldots \ldots \ldots, 11$

8 Teen Center Sump $\ldots \ldots \ldots \ldots \ldots \ldots \ldots \ldots \ldots \ldots$

9 The Convention Center Complex at $\mathrm{T}$ or C ..... 13

10 The Senior Citizens Center $\ldots \ldots \ldots \ldots \ldots \ldots \ldots 14$

11 The Heating system $\ldots \ldots \ldots \ldots \ldots \ldots \ldots \ldots \ldots 16$

12 A Modine Heating Unit $\ldots \ldots \ldots \ldots \ldots \ldots \ldots \ldots 17$

13 A Modine Heating Unit with Gas Heater $\ldots \ldots \ldots 17$

14 Heating Units in the Center ............. 18 
TABLE OF CONTENTS

Abstract ........................ i

List of Figures $\ldots \ldots \ldots \ldots \ldots \ldots \ldots \ldots \ldots \ldots \ldots \ldots$ i

Introduction $\ldots \ldots \ldots \ldots \ldots \ldots \ldots \ldots \ldots \ldots \ldots \ldots \ldots \ldots$

The Well Drilling .................. 4

The Heating system Design and

Installation .................... 12

Financing of Geothermal Utilization in

Truth or Consequences .............. 19

References ....................... 23

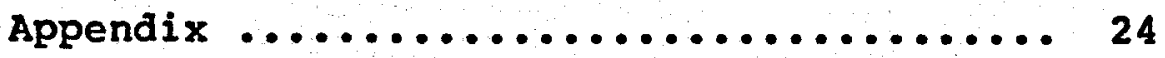


GEOTHERMAL SPACE HEATING FOR THE SENIOR CITIZENS

CENTER AT TRUTH OR CONSEQUENCES, NEW MEXICO

\section{Introguctetion}

The City of Truth or Consequences is located in Sierra County in south central New Mexico. The City is characterized as a fixed-income retirement community, supplemented by recreation, agriculture and ranching which also make up part of the economy. The 1970 census showed that 25 percent of the population is 65 years of age and older and 36 percent of these people are below the poverty level (1). The senior citizen population increases during the fall because of "snowbirds" migrating from the north to winter in a warmer climate.

The Truth or Consequences Geothermal region is an area of about 64 square miles. It includes about 74 wells and springs of which 40 contain water with temperatures above 77F, the highest temperature recorded as 114F. Two of these sources are springs, seven are sumps, and the remaining 31 are wells ranging in diameter from 2 to 30 inches and depth from 6 to 442 feet $(2,3,4)$. The geothermal area occurs along the west side of the Rio Grande between the northwest trending Mud springs Mountains and the sierra Caballos shown in Figure 1. Historically the area has been referred to as the Las Palomas Hot Springs, Caballo Hot Springs, and Hot Springs before being changed to Truth or Consequences in 1950. The thermal springs have been used for many years as spas and mineral baths for therapeutic purposes (4). With hot water sources located all around the area, it was unexpected that we would drill into a formation which would be unfractured and therefore dry. 
Geologically the rocks in the area range from Precambrian to the Recent Era. The formations of principal concern are the alluvium adjacent to the Rio Grande river and the magdalena limestone of Pennsylvanian and Permian ages. Precambrian rocks outcrop along the western base of the Caballo Mountains, along the Rio Grande, at the south end of the Mud Springs Mountains, and in and near Truth or Consequences. These rocks are mainly red and reddish brown granite and form relatively impermeable boundaries to the northward and eastward movement of the groundwater in the alluvium between williamsburg and Caballo Reservoir (4). Paleozoic rocks are exposed in the mountainous areas and also underlie the Rio Grande Valley at depth. They are relatively impermeable, but form aquifers where they are broken by fault zones, controlling the movement of the groundwater west of the Rio Grande. Thermal waters under artesian pressure come from the magdelena group of Pennsylvania and Permian ages in a small area of the town of Truth or Consequences (2). Many of the wells in the area are artesian having heads ranging from o to 58 feet. Mesozoic era rocks are sandstone and late Cretaceous shale. The alluvium in the Rio Grande is composed of gravel, sand, silt, clay and conglomerates. Lenses of clay are embedded in the sand and gravel extending westward from the river. The alluvium is hundreds of feet thick in most of the area, and one well penetrated more than 2100 feet of sediment (2).

The thermal waters discharge into the Rio Grande at Truth or consequences. The pressure within the aquifer is affected by the stage of the river which in turn is controlled by the release of water from Elephant Butte Reservoir. Nonthermal artesian waters discharge into the Rio Grande through shallow, unconfined aquifers. The alluvium is saturated at a depth of 10 feet under most of the Rio Grande flood plain from 


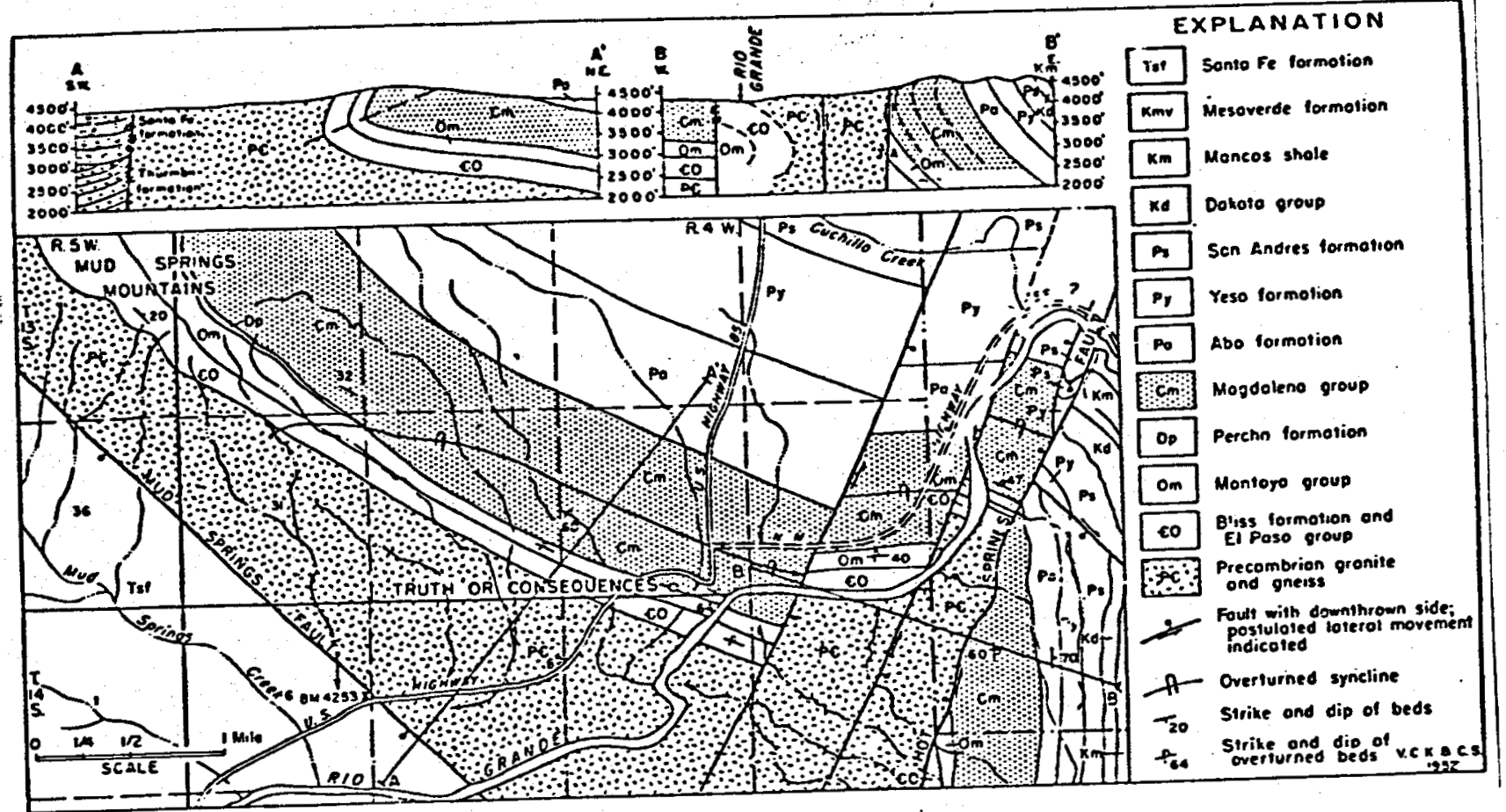

(Theis, Taylor and Murray, 1942)

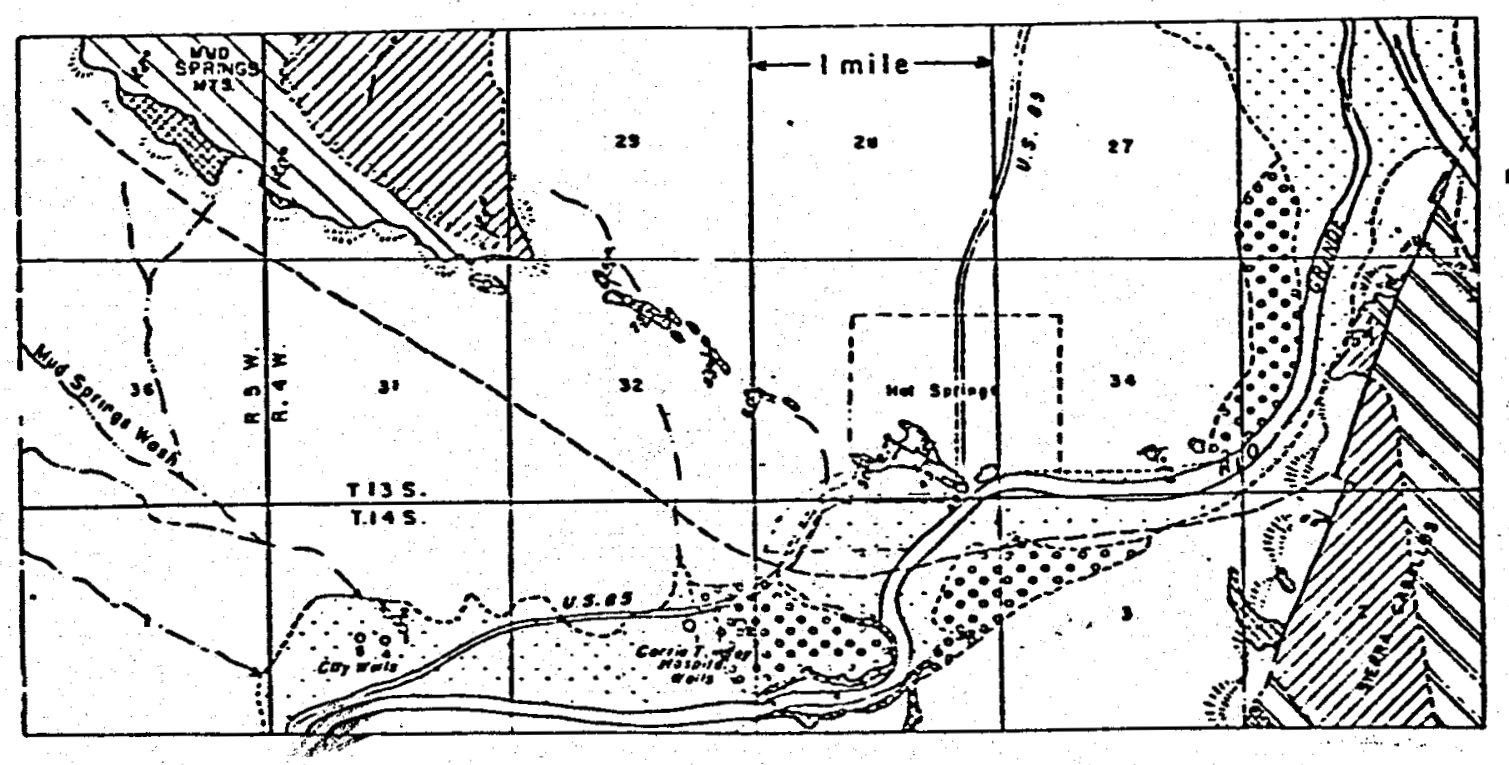

EXPLANATION

(Kelley and Silver, 1.952)

Figure 1. The Geology of the Truth or Consequences area. 
williamsburg to Caballo Resevoir. Theis et. al. (5) report coefficients of transmissibility ranging from 3.4 to $5.5 \times 10^{5}$ gallons/day/foot for the magdalena limestone aquifer in and around Truth or Consequences.

The_Well__Drililing

The first bid package to drill the geothermal well at Truth or Consequences was sent out to potential drillers in october of 1979. The response was good with about five drillers submitting bids. Unfortunately, all of the bids exceeded the $\$ 19,800$ available for drilling the geothermal well. Therefore, it was necessary to revise the specifications and send the bid package out again. (Technical specifications are in the Appendix.) The reasons for the large discrepancy between the monies available and the bids on the first solicitation (the bias ranged from $\$ 35,000$ to about $\$ 60,000)$ are probably due to a number of factors. First, drillers in the area do not have a lot of experience in drilling geothermal wells and their bids reflected this. second, there has been a great deal of water and oil well drilling going on in the area and most drillers were very busy, therefore resulting in it being a sellers market. Third, and perhaps the most logical reason is that drillers do not usually operate on fixed-cost contracts as is necessary when dealing with the University.

When the second bid package came due in February 1980 a an acceptable bid was received and a contract was sent to the driller. (Copies of the oil Conservation Division Forms G-101, G-102 and G-103 are included in the Appendix.) He began drilling during early May 1980 but he did so without having returned a signed contract and posting a performance 
bond as required by the University. He was informed of this and decided that he would not continue with the project. This again left us without a driller. We were then free to negotiate since we had bid the project twice and not found an acceptable ariller willing to do the job. However, because of the large amount of drilling going on in the area, we had a great deal of difficulty finding a driller with whom to negotiate. Finally, a new set of technical specifications acceptable to a driller and us was arrived at in October of 1980 and we signed a contract with Larjon Drilling of Las Cruces. (These specifications are also included in the Appendix.) Because of prior commitments, Larjon was unable to begin arilling until March 1981.

From the local geology and experience of the first driller, we knew that there was limestone at the surface and believed that it extended no deeper than 50 feet. After going 50 feet and still finding limestone, the driller decided to switch to a cable arilling rig. When the hole was finally completed to the contracted depth of 250 feet it was dry. This was during the first part of June 1981. We then took a temperature $\log$ of the hole and capped it as specified by the state Engineer (revised OCD form G-103 is included in the appendix). Figure 2 is the site of the hole. The man on the right is the City Manager at Truth or Consequences Mr . Quentin Drunzer and he is standing on top of the capped well (HS 476) Shown in Figure 3 is a piece of the "cherty" or hard limestone which was drilled from the well. Figure 4 is the temperature log of the ary well.

At this point it was necessary for us to resort to our contingency plan which was to use an old sump located in the Teen Center adjacent to the Senior Citizens Center. This sump was the old town well (HS 24) where visitors and citizens 


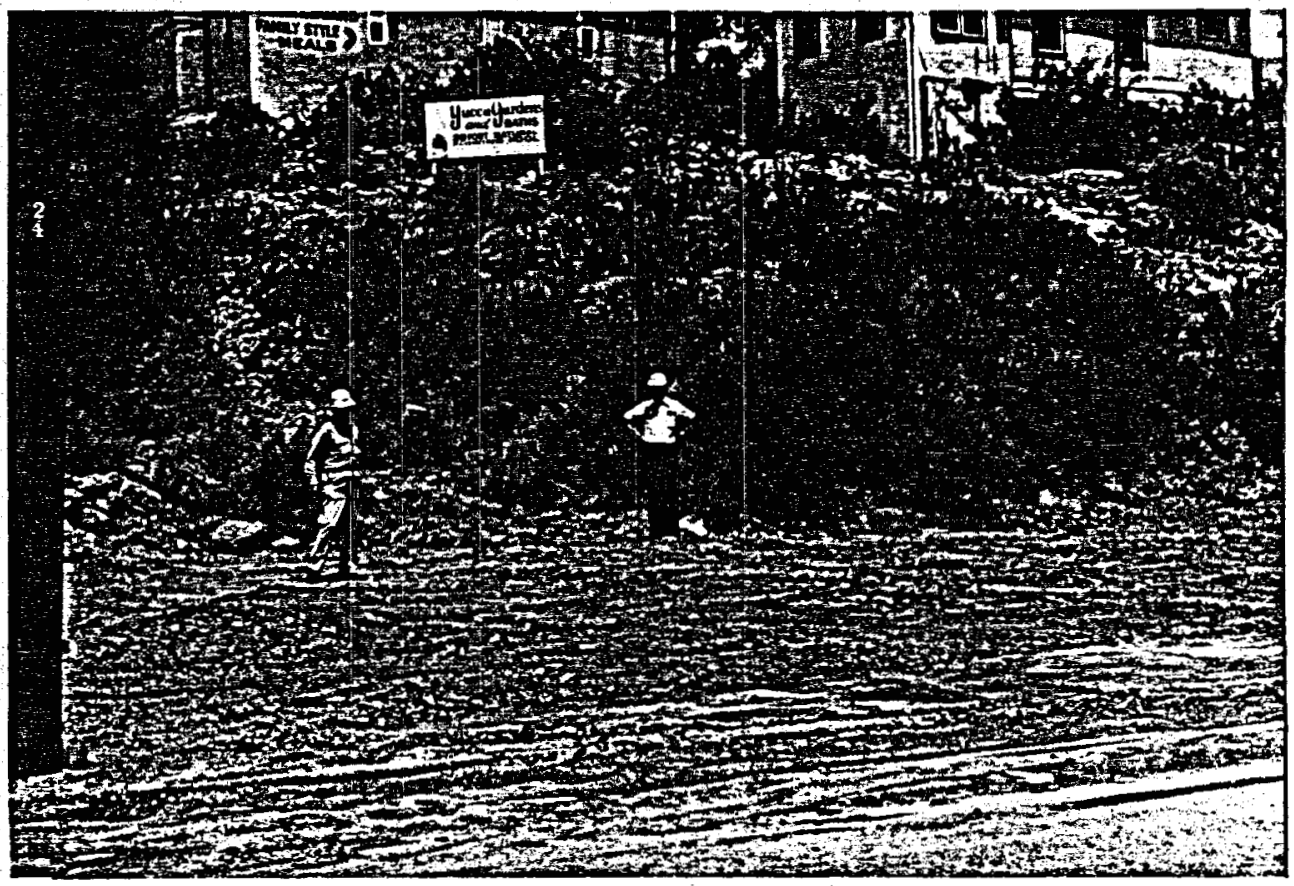

Figure 2. City Manager Quentin Drunzer and Mr. Alfred Armijo inspect the site of the original

drilled we11 HS-476. Mr. Drunzer is standing on the capped well.

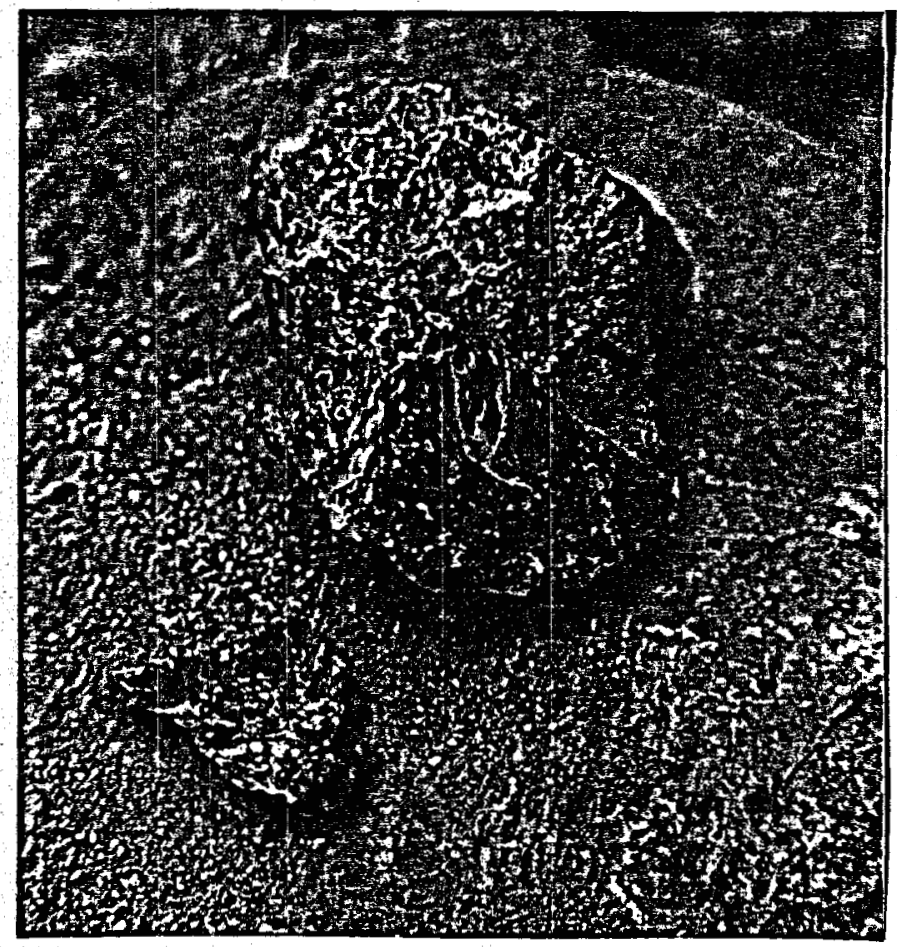

Figure 3. A piece of limestone through which the dry well HS-476 was drilled. 


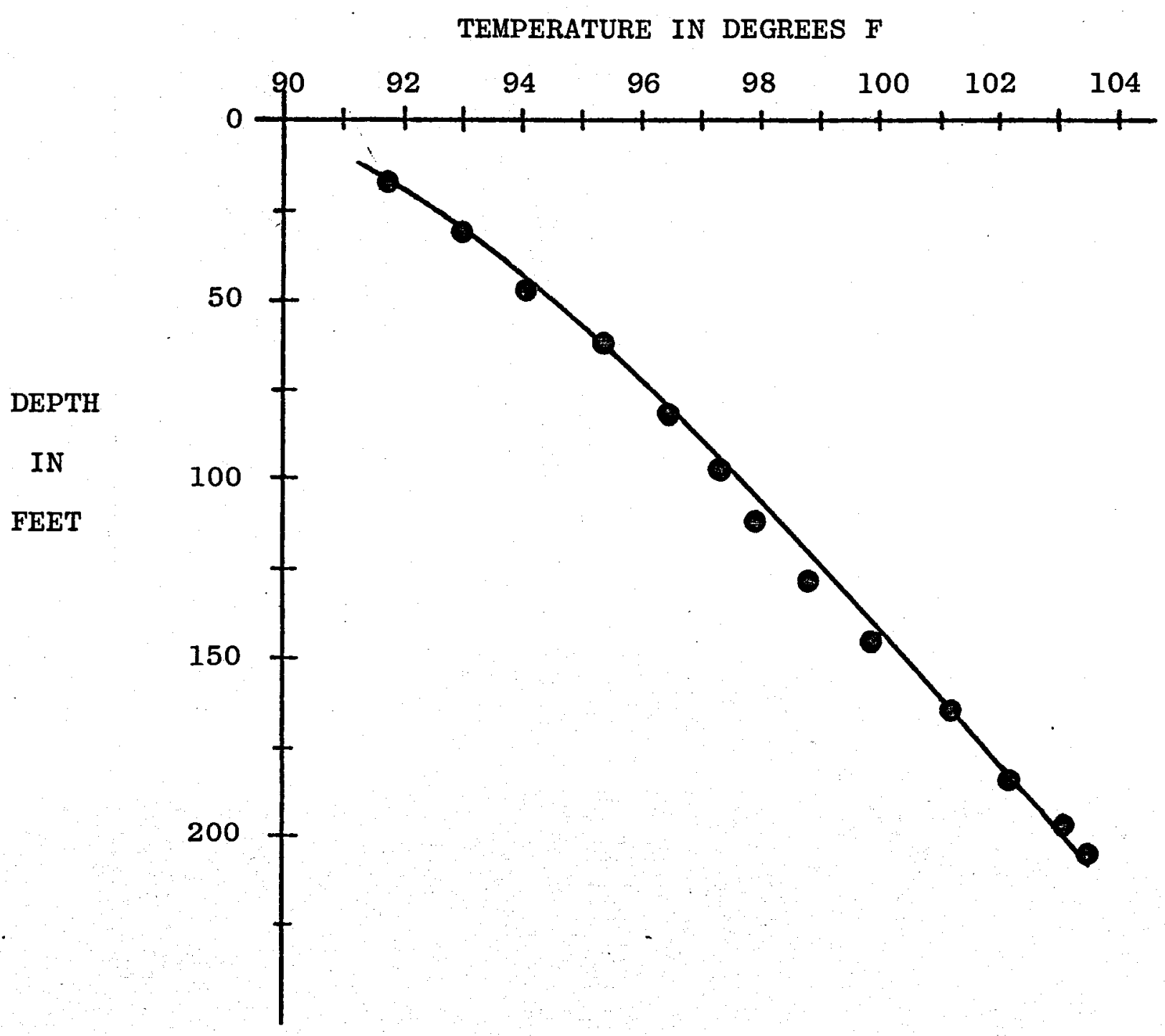

Figure 4. Temperature $\log$ of the dry well HS-476. 
alike came to drink of the geothermal waters. The age of the well is unknown but estimated at 50 years and it is about 60 feet deep. We had earlier considered using this well for the geothermal heating system and had run a pump test on it, but had opted for drilling a new well and possibly finding hotter water. Figure 5 is the temperature time history of the water pumped from this sump in November of 1978. Shown in Figure 6 is the location of the sump and the original site of the dry well in reference to the building in which the senior citizens Center is located. From the point of view of convenience, one could hardly ask for a more convenient location than the old City well. Figures 7 and 8 show the hot water sump. Water is available at a depth of about 2 feet and at a temperature of 107F. The geothermal water is pumped from the sump at a rate of about 30 gallons per minute and a depth of about 5 feet through the space heating system in the Senior Citizens Center.

During the time that the negotiations for the drilling were proceeding, the water right for 30 acre feet of water per year was secured (BS-476 in the Appendix). This water right has been transferred to the sump in the Teen Center (HS 24). There was a protest filed on the original well and the water $r$ ight was granted after the appropriate hearings were conducted. The nature of the protest was that other users of geothermal waters in Truth or Consequences were concerned that the City's pumping of water would affect the natural flows to their bath houses. Expert testimony indicated that it was unlikely that the 30 gallons per minute pumping rate would affect the natural flow of water. Furthermore, the city Council agreed to stop pumping in the event that any disturbance to the natural flow could be shown to have resulted from the pumping of the well. The State Engineers office was satisfied with this and granted the water right. 
TEST: HS 24

DATE: Nov. 22,1978

PUMPING RATE: $4.3 \mathrm{gpm}$

DRAWDOWN: Negligible

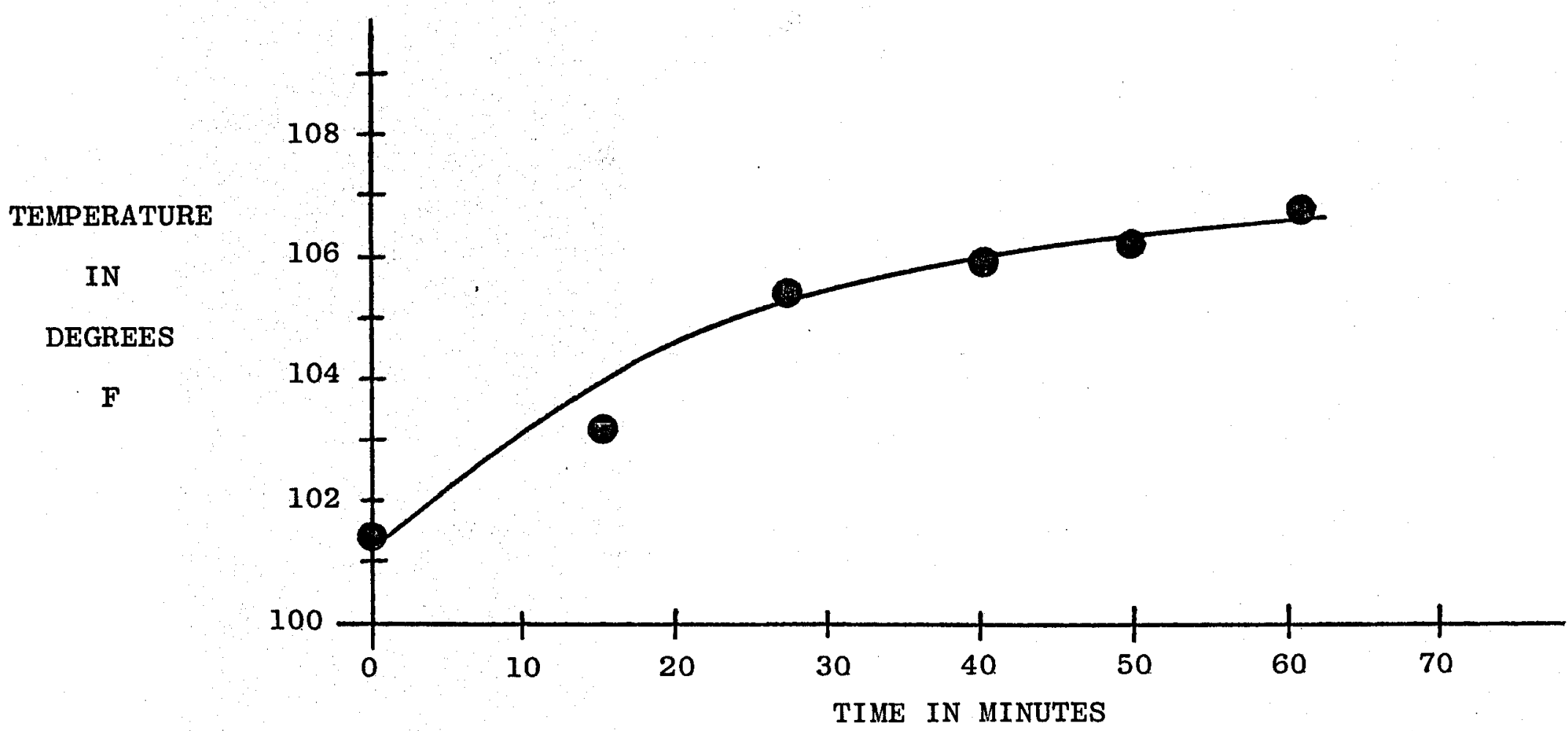

Figure 5. Time-temperature $10 \mathrm{~g}$ of the pumped sump in the Teen center (HS-24). 


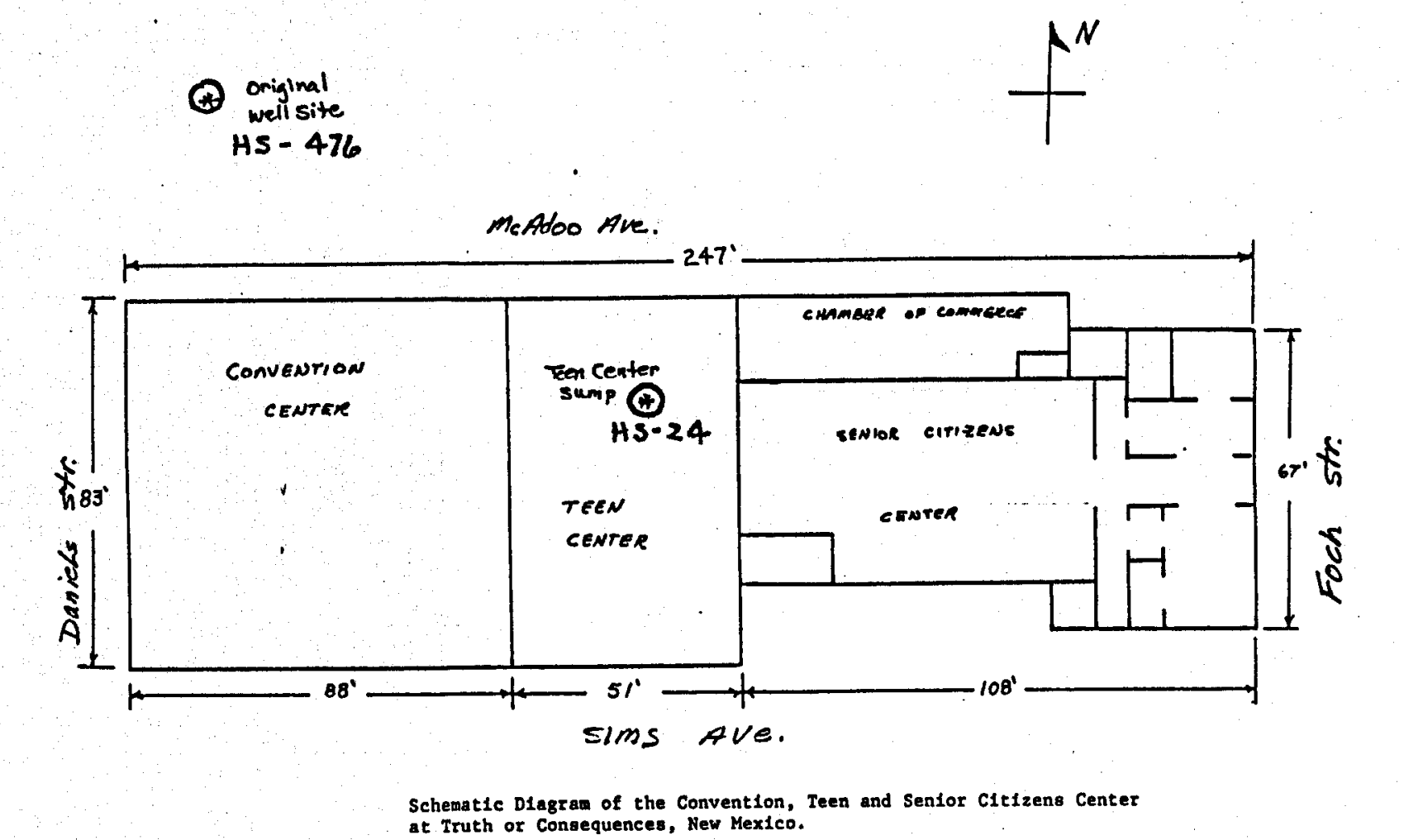

at Truth or Consequences, New Mexico.

Figure 6. Locations of HS-476 and HS-24. 


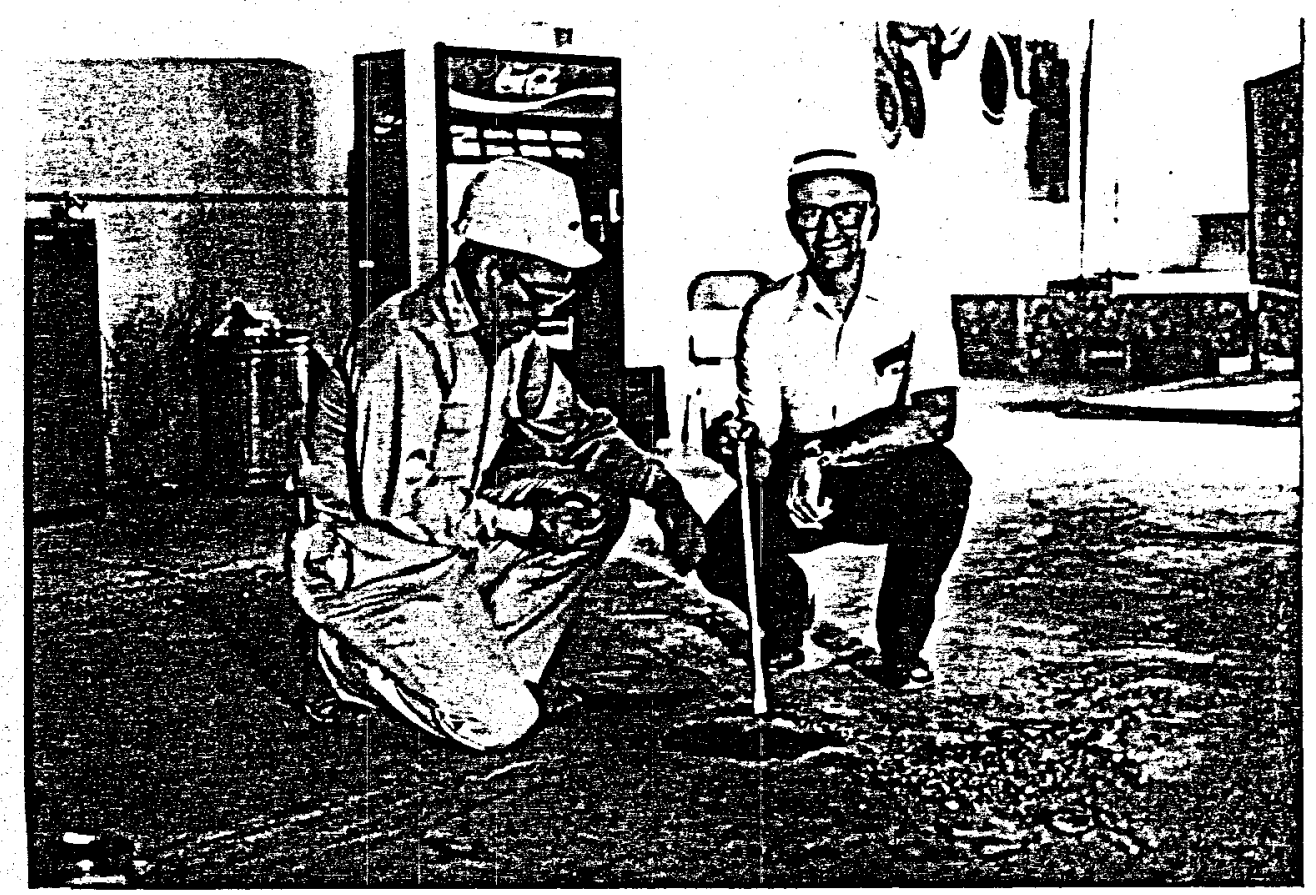

Figure 7. Mr. Drunzer and Alfred Armijo inspecting the sump in the Teen Center. The water level is about $21 / 2$ feet below the surface.

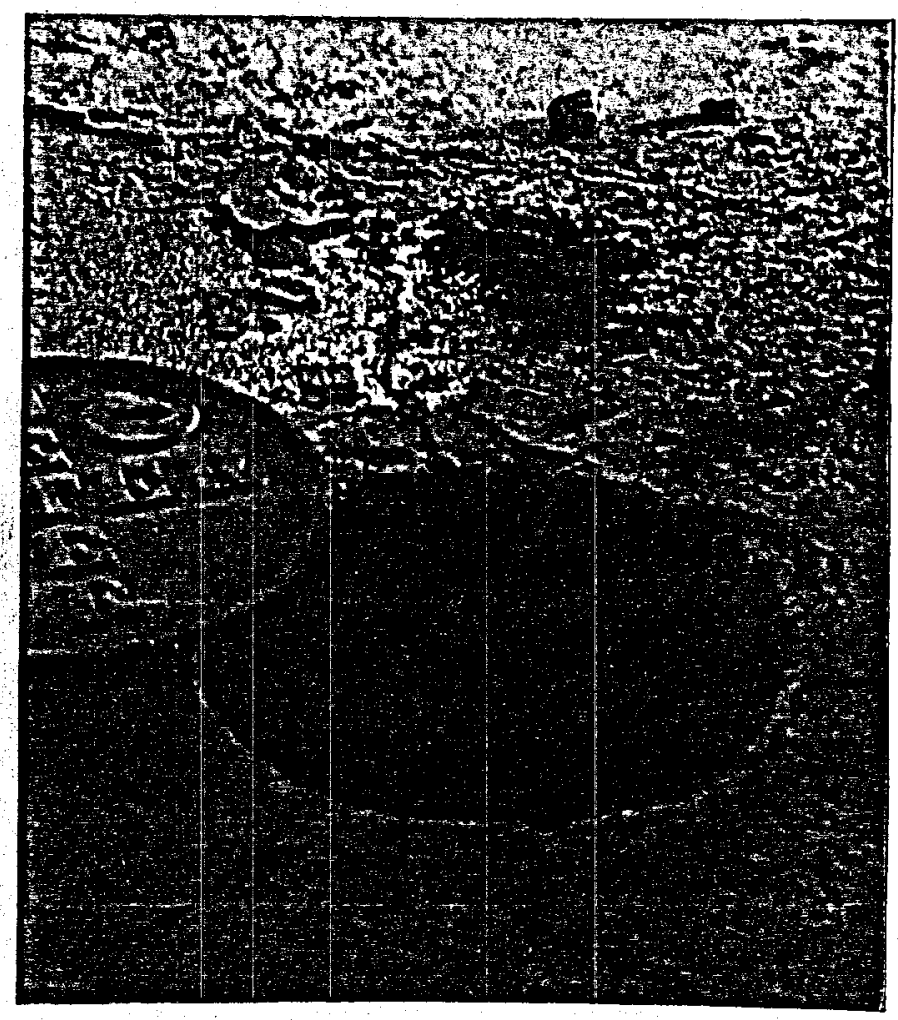

Figure 8. The Teen Center sump (HS-24). 
The_He_eating_System_Designn_and__Instalallattion

To estimate the heating loads of the senior Citizens Center, we used the gas utilization of the structure for the winter of 1978. The gas usage is reported for the combined structure, shown in Figure 9, of the Teen Center, Convention Center, Chamber of Commerce and the Senior Citizens Center. since the only part of the building which is used on a regular basis is the Senior Citizens Center, it was difficult to determine exactly what the heating load for that building is. The best estimate which can be made is that the peak winter hourly heating load is probably in the range of 120,000 to $150,000 \mathrm{BTU} / \mathrm{HR}$. Figure 10 is a picture of the part of the building which is the senior citizens center. This is an old adobe building which had formerly been the court house; the Teen Center, Convention Center and Chamber of Commerce are more recent additions and are Butler type buildings. Because this number is a peak load which will most likely occur in the early morning hours when the building is unoccupied; because it is a conservative estimate; and because we do not know if $107 F$ is the hottest water we will get from the sump under extended operation; the heating system was designed to meet a 105,000 BTU/HR load.

Initially it was the design concept to use a single heat exchanger to transfer the energy from the geothermal waters to the room air. However, it is easier to install piping than it is to install air ducts particularly in retrofit situations, so we decided to use heat exchanger - fan units manufactured by Modine. These units extract the energy from the hot water and supply it to the room air locally. Three v-139 units 


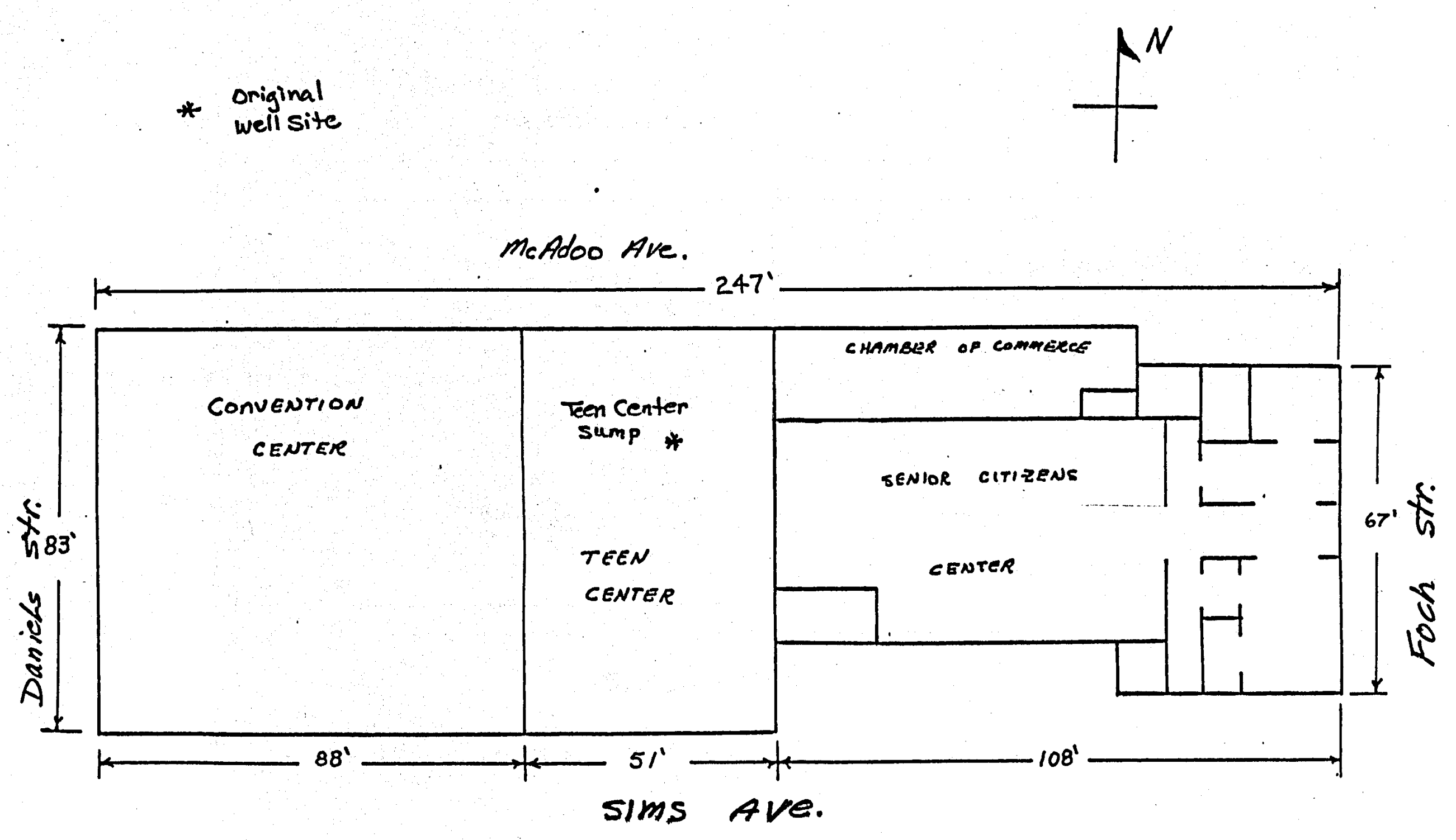

Figure 9. Schematic Diagram of the Convention, Teen and Senior Citizens Center at Truth or Consequences, New Mexico. 


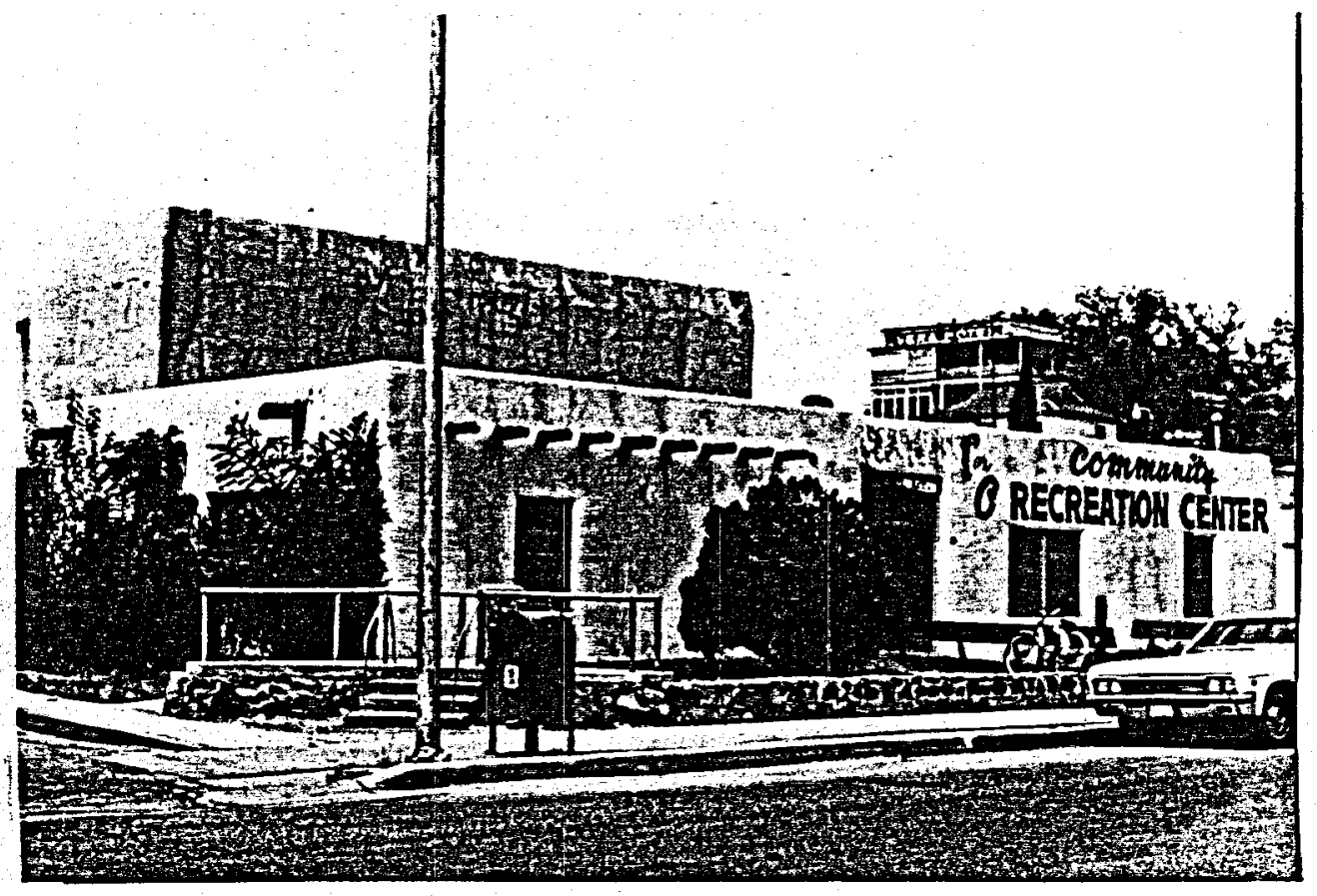

Figure 10. Photograph of the Senior Citizen Community Center at Truth or Consequences, New Mexico. 
derated for hot water operation were installed in the center as shown in Figure 11. (Detailed information on these units is contained in the Appendix.) These units will supply about 35,000 BTU/HR each to the Center when they are operating. Figure 12 is a close up picture of one of the units as it is installed in the center. Figures 13 and 14 also show the unit with the existing gas fired heater in the background. All of the piping in the system is 2 inch insulated with Armaflex and restricted to $3 / 4$ of an inch through the heating units. Balancing valves are included as shown in the system schematic as are air bleed valves.

Referring to Figure 11, one can follow the operation of the heating system. All three units are controlled off of a single thermostat which is set to come on at a temperature of 70F. The existing gas fired heaters will be used as a backup system and are set to come on at a temperature of $65 \mathrm{~F}$. Once the geothermal heating system is activated, water is pumped from the sump passes through a surge tank and the heating units and is discarded to the hot water drain shown in Figure 11. The system is automatic, simple and should operate for a number of years. The City of Truth or Consequences is monitoring the gas usage of the building to serve as an estimate of the system performance.

The City is very pleased with the operation of the system and, because of their enthusiasm, Dr. Mancini contacted the Modine Manufacturing Company, Inc. of Racine, Wisconsin, the company supplied the original heating units which were used in the building. Modine agreed to donate six additional units so the city of Truth or Consequences can expand the system to heat the two remaining parts of the building, the reen and convention centers. The city is presently installing the piping to complete the installation. 

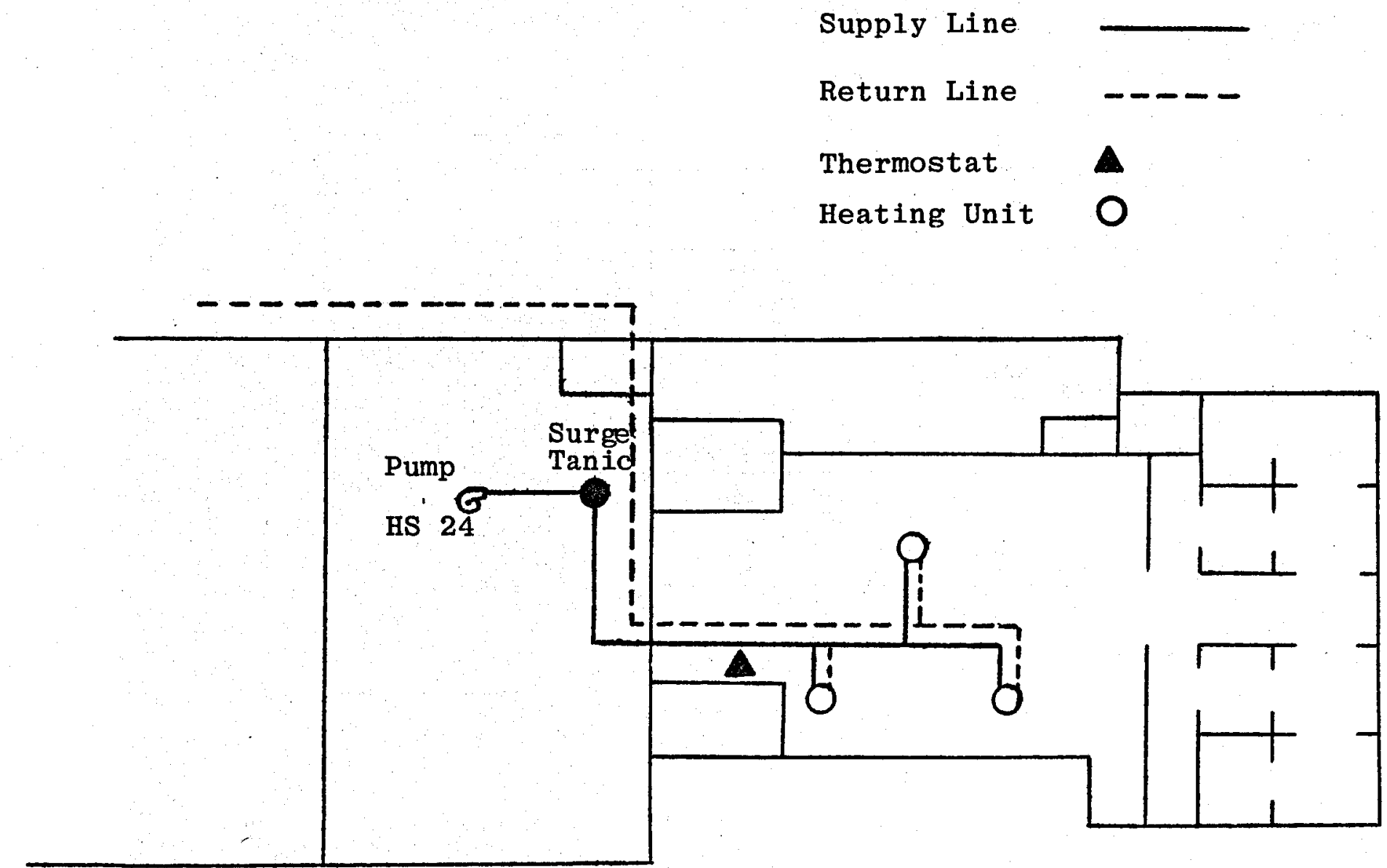

Figure 11. The Heating System lay out. 


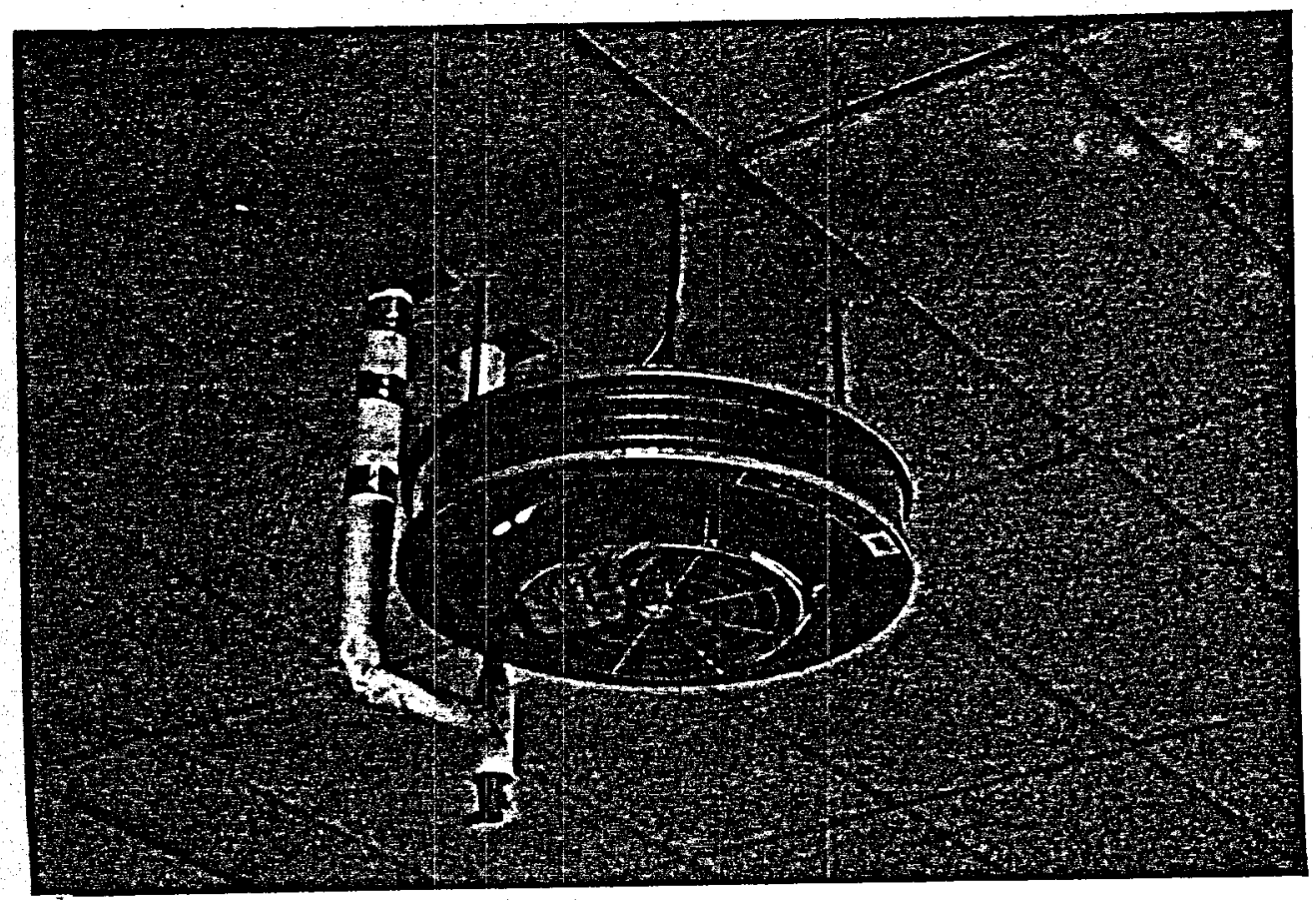

Figure 12. Close-up photograph of Modine V-139 heating unit.

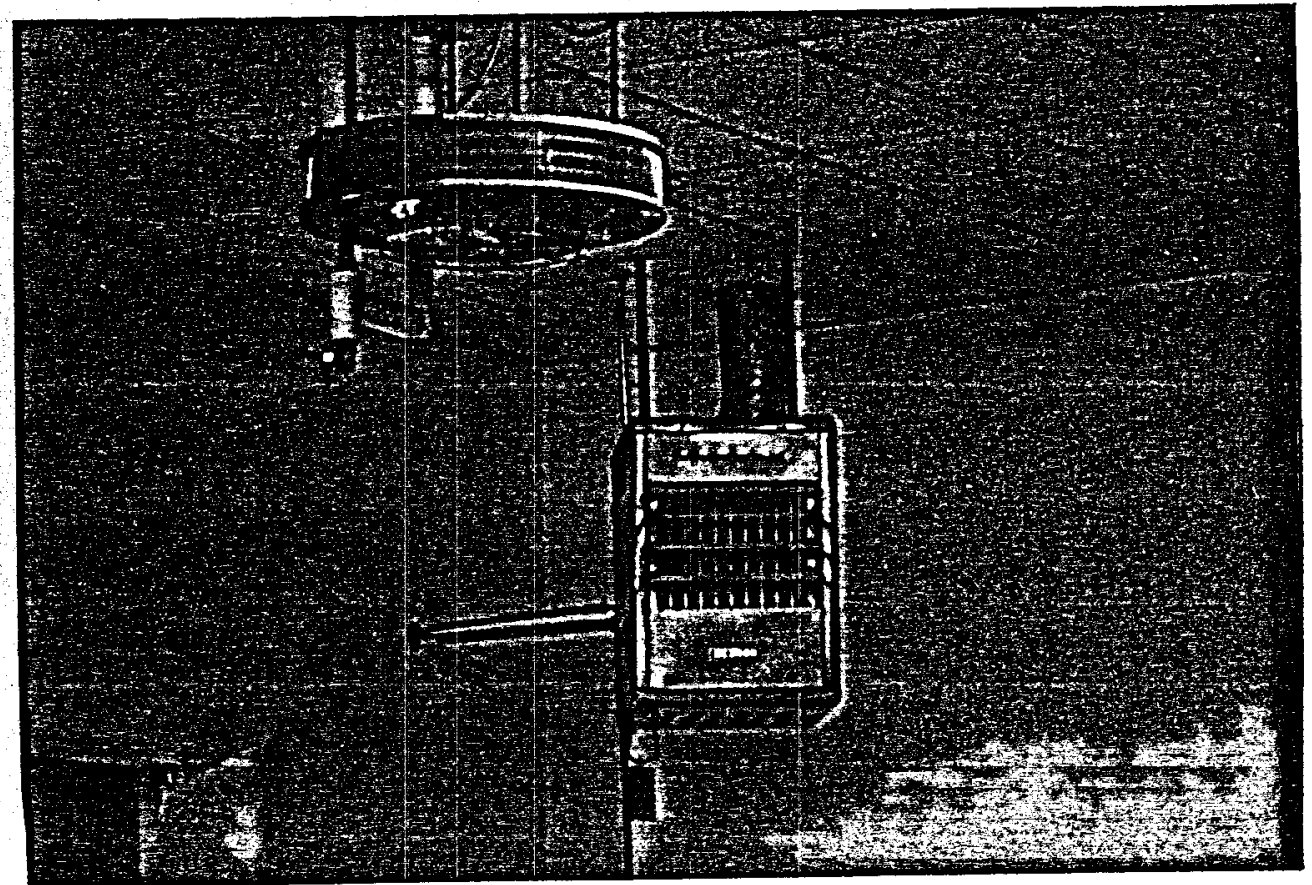

Figure 13. Modine unit with gas heater in the background. 


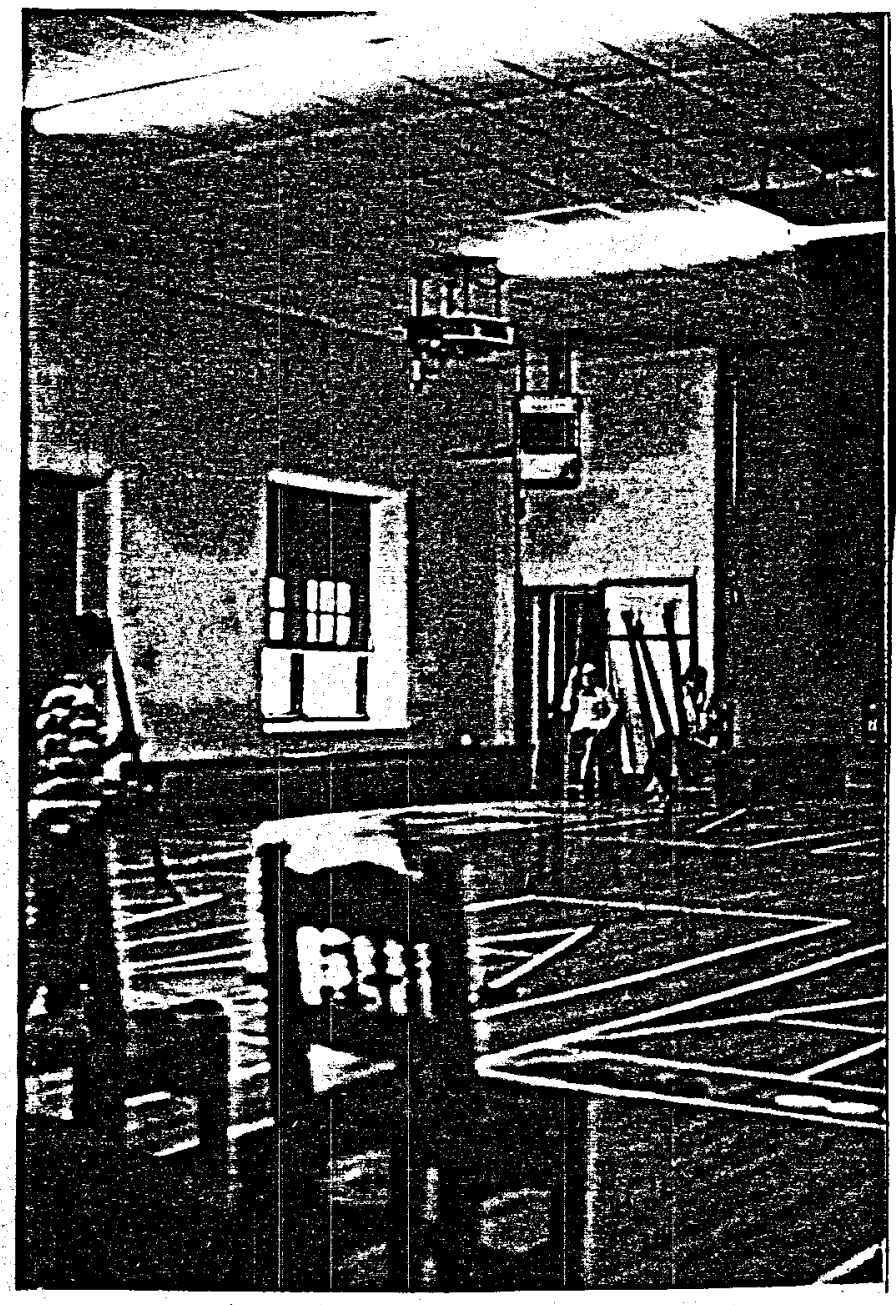

Figure 14. The Senior Citizen Center with heating units. 
The original cost of the system for the Senior Citizens Center is shown below.

3 Modine Heater Units and controls .... $\$ 3672.00$

Pump and surge tank ............... 361.63

Installation and Piping ............ 7905.90

TOTAL COST $\$ 11,939.53$

The_Finanging_of_Geothermal_utilizization_at_tTruth_or Consegeguenceses__New_Mexi

This part of the project was to determine the problems associated with attracting local financing of geothermal energy projects. The information presented herein was gathered through interviews with local lending institutions and other influential citizens. This summary is based solely on the statements of the people interviewed and does not analyze any actions or events which would tend to support or invalidated these statements. Furthermore, it represents the author's interpretation of the opinions and attitudes of the financial community of the city of Truth or Consequences.

As stated earlier, there is a history of the use of geothermal waters in the City of Truth or Consequences for mineral water baths. This is because in the downtown area the water table is within 5 feet or less of the land surface. One bath house has even used the hot water to heat motel rooms and, while others have discussed similar installations, none have done so.

The citizens of Truth or Consequences are basically 
knowledgeable about the use of geothermal energy. At the beginning of this project, a protest was filed against the water right application of the City. Both of the local newspapers reported extensively on the appeal, and two public hearings were held to discuss the project with the local citizens. One of these hearings was broadcast by the local radio station. The water right hearing was held in the city Hall and was well attended. Therefore, the citizens are well informed about the project and about the processes involved in the utlilization of geothermal energy.

The local financial institutions in Truth or Consequences are limited to two banks and two savings and loan associations. The capacity of financial institutions to provide loans is limited to a percentage of their resources, and their growth is extremely limited. As an example, during the year 1978, the bank's deposits increased only 2.8 percent while the toital deposits in New Mexico increased by 12.1 percent. Furthermore, it was determined that if a loan of over $\$ 100,000$ is needed, the banks would have difficulty providing the finanacing. Banks in Albuquerque and Las Cruces have larger loan limits, but they do not have extensive knowledge of the conditions at Truth or Consequences. summarizing, we found that the financial capacity of the local banking institutions is very limited.

Dr. Tom Gebhard met with the president of the largest bank in Truth or Consequences. The banker expressed support for the development of alternate energy sources primarily because of the isolation of the community from other energy sources. He was knowledgeable about the local geothermal waters, and the bank even has a hot water bath in its basement. He stated that the bank would lend money for geothermal space heating if the economics of the project were 
favorable and the payback period was reasonable. Traditional loan requirements would have to be met and the project could not exceed the loan limitations of the bank.

To determine the attitudes of the remainder of the community, a dinner meeting was held with the community leaders from both banks, both newspapers, the school board, the bath house owners, and an attorney. This meeting was sponsored by a group of university researchers surveying community attitudes which would adversely inpact the development of geothermal energy. These researchers from the College of Business Administration at New Mexico state University have conducted similar dinner meetings in Albuquerque and Las Cruces. After the meeting ended, they concluded that the community leaders understood the limitations on the development of geothermal energy and have a more sophisticated understanding of the technical problems than any other community in New Mexico.

The representatives from both of the banks agreed on all financial problems associated with loans to geothermal projects. Loan requirements must be the same as for any other loan processed by the banks, and limits would restrict the capacity for financing. The development of geothermal energy resources would receive more favorable consideration than the development of solar energy because geothermal energy is viewed as a more dependable energy source during extreme cold weather. Loan guarantee programs, similar to the small Business Administration Loan Guarantee Progran, are preferred because the loan guarantee limits the potential losses of the banks.

The rest of the community leaders voiced strong support for the development of geothermal energy. However, some 
hesitation existed when local financing was the only method for development. The public schools would convert to geothermal space heating if it is shown that money will be saved. The community leaders appeared to support the hope that federal and state financing for initial projects would demonstrate that geothermal space heating is cost effective and that an understanding of technical details would occur in the community.

\section{Summary:}

1. Local financing can be provided when the local financial institutions understand the economic benefits of using geothermal energy.

2. Local financing can be obtained when short payback periods exist.

3. Standard requirements for loan security must be met.

4. Geothermal energy is considered to be a more reliable energy resource than solar by the local community.

5. The distribution of accurate information on the development of geothermal energy will create a supportive attitude within the community even if a project is controversial. 


\section{REFERENCES}

1. Estimates of the $60+$ Populations for Counties and PSA'S OHDO - 77 - 20085, U.S. Department of Health, Education and Welfare, November 1976.

2. Summers, W.K., Catalog of Thermal Waters in New Mexico, Hydrologic Report No. 4, New Mexico Bureau of Mines and Mineral Resources, Socorro, New Mexico, 1976.

3. Minton, E.G., Investigation of Hot Springs Artesian Basin, New Mexico, New Mexico State Engineer, 14th and 15th Biennial Reports, pp. 349 - 365, 1941.

4. Murray, C.R., Groundwater Conditions in the Nonthermal Artesian Basin South of Hot Springs, Sierra County, New Mexico, New Mexico State Engineer, Tech. Report 10, 1949.

5. Theis, C.V., Taylor, C.G., Jr., and Murray, C.R., Thermal Waters of the Hot Springs Artesian Basin, Sierra County, New Mexico, New Mexico State Engineer, 14th and 15th Biennal Report, pp. $419-492,1941$. 


\begin{abstract}
APPENDIXES
ORIGINAL TECHNICAL SPECIFICATIONS FOR

DRILLING THE WELL AT TRUTH OR CONSEQUENCES ......... 1-A

NEGOTIATED SPECIFICATIONS FOR DRILLING

THE WELL AT TRUTH OR CONSEQUENCES ............... 13-A

OCD FORM G-101 .......................... 15-A

OCD FORM G-102 ............................ 16-A

OCD FORM G-103 $\ldots \ldots \ldots \ldots \ldots \ldots \ldots \ldots \ldots \ldots \ldots \ldots \ldots \ldots \ldots \ldots$

REVISED FORM G-103 ........................ 18-A

APPLICATION FOR WATER RIGHT FOR HS $476 \ldots \ldots \ldots \ldots \ldots \ldots$ 19-...

TRANSFER OF WATER RIGHT TO HS $24 \ldots \ldots \ldots \ldots \ldots \ldots \ldots \ldots \ldots$

INFORMATION ON THE MODINE HEATING UNITS .......... 21-A
\end{abstract}


ORIGINAL

TECHNICAL SPECIFICATIONS

Location and General Description

These specifications are for drilling a hot water production well at STI/4 SWI/4 SE1/4, section 33, Township 13 South, Range 4 West, near the Senior Citizen's Center in Truth or Consequences, New Mexico. An approximate description of the job is as follows:

1. Drill a 9-inch diameter hole to a depth of 500 feet.

2. Install a 2-inch diameter PVC pipe, capped at the bottom, through the entire length of the hole. Fill the pipe with water and wait 24 hours for the temperature gradient to stabilize. The temperature $10 \mathrm{~g}$ will be recorded by New Mexico State University personnel.

3. Pull out the PVC pipe and allow geophysical logging in the hole to be done by a New Mexico State University contractor.

4. Order and install a $65 / 8$-inch $0 . D$. stainless steel screen and casing. The lengths and locations of the screen and casing will be determined by the New Mexico State University representative on the basis of geophysical logs and other information.

5. Gravel pack and cement the annular space outside the screen and the casing respectively.

6. Develop the well until it is cleaned of sand. It will be bailed for eight hours or until a good sample can be obtained.

7. Test pump the well for 24 hours.

Local Conditions and Geology

Bidders will be held as having examined the drilling site in order to aquaint themselves with the conditions of the area. The exact location of the well will be decided in consultation with the driller, City of Truth or Consequences and the New Mexico State University representative. Convenience of the driller for the ease of drilling, mud pit and disposal of water will be taken into consideration, but the decision of the New Mexico State University representative will be final on all such matters. The driller will cooperate with the city officials and New Mexico State University representatives on all matters affecting the area during drilling.

A driller's log of a well in Block 104, SE1/4 SW1/4 SE1/4, section 33, Township 13 South, Range 4 West, near the proposed well is given in Figure 1. Theis log, taken from Theis, et. ai. (1941) is probably representative of what may be expected during drilling of the proposed well. On the basis of this well $\log$ and the geology of the area, it is expected that the Magdalena limestone formation, which consists of Iimestone and shale, often weathered, will be encountered through the full depth of the hole below the top 50-60 feet of alluvium cover. A complete description and discussion of the geology of the area and the occurrence of hot water can be found in Theis (1941). The bidder will be expected to familiarize himself with the known and expected geologic and geothermal hydrologic conditions at the site. For further information, the bidder may contact Dr. Lokesh Chaturvedi, Department of Civil Engineering, New Mexico State University, Las Cruces, New Mexico, Telephone: (505) 646-3233. It is 
Log by L. A. Gordon, driller

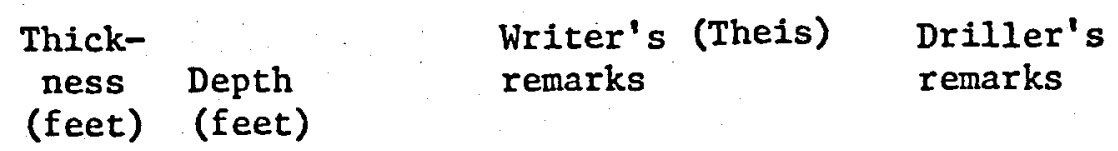

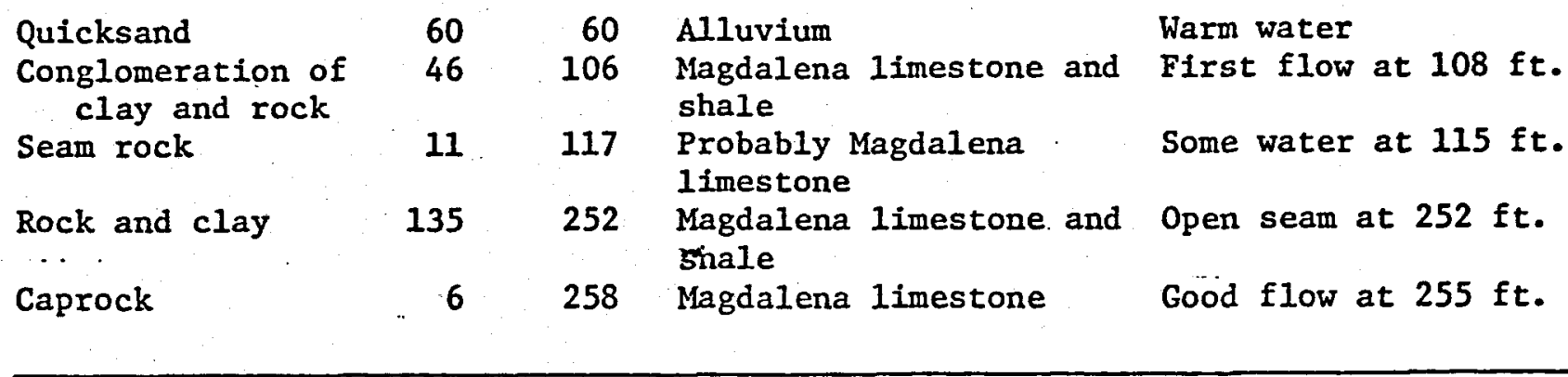

Figure 1. We1l 31 in Block 104, SE1/4. SWl/4 SE1/4, sec. 33, T. 13 S., R. 4 W., Hot Springs Townsite

Temperature of water $112^{\circ} \mathrm{F}$ (Theis, 1941)

emphasized that the information on the expected geologic conditions given here is only for the guidance of the bidders.' These conditions are not guaranteed by the university.

Equipment and Personnel to be Furnished by the Contractor

The contractor shall provide the necessary rotary drilling rig, all tools, equipment, accessories, water, mud, power, bits, lighting, well casing, screen, current, gravel and experienced personnel necessary to conduct without difficulty the drilling, casing, grouting, and cementing operation described in these specifications.

Equipment and Personnel to be Furnished by NMSU

Samples of drill cuttings will be obtained at 10 feet intervals by NMSU personnel. Geophysical and temperature logging of the hole will be handled by the university.

The contractor will cooperate with the university personnel in obtaining the cuttings and in performing the logging.

Detailed Technical Specifications

1. The drilling is to be done in the Hot Springs Artesian Basin and therefore has to comply with the requirements and guidelines of the New Mexico State Engineer. Only contractors with a license to drill in an artesian basin in New Mexico should submit a bid. The requirements of the State Engineer for drilling an artesian well are given in Appendix A. 
The bidder should familiarize himself with these requirements before submitting a bid.

2. Bore hole - The bore hole should be atleast 9 inches in diameter and should be sufficiently straight and plumb so that the casing can be properly installed and gravel packed all around, that tools and bailers can be run freely to the bottom of the hole.

3. Logging - Soon after the drilling is completed a 2-inch PVC pipe will be installed by the contractor through the full length of the bore hole. This pipe should be sealed at the bottom, should not leak at the joints and should be filled with water and left in the hole for 24 hours in order that the temperature gradient stabilizes. Temperature gradient measurements will be made by New Mexico State University personnel. The PVC pipe will then be pulled out and a suite of geophysical logs will be run in the uncased hole. It is understood that the driller will need to maintain a positive head in the hole throughout this operation to prevent caving.

4. Casing - The casing shall have a minimum inside diameter of 6 inches and shall meet the minimum API specifications as given in Appendix A. A 6 5/8-inch $0 . D$. casing should be grade F-25, should have a wall thickness of . 245 inches and a weight with couplings of $17 \mathrm{lbs} / \mathrm{ft}$. Only threaded casing shall be used. The screen shall be atleast 6 inches I.D. and shall be a Johnson well screen or equivalent.

5. Gravel packing - The annular space outside the screen will be packed with clean screened pea gravel which should contain no calcareous or organic material.

6. Cementing - See Appendix A for cementing requirements (State Engineer's requirements).

7. Development - The well will be developed until it is cleaned of sand. It will be bailed for eight hours or until a good water sample can be obtained.

8. Test pumping - The contractor will install a temporary pump and test pump the well for 24 hours in order to determine the size and placement of a permanent pump.

Inspection

All casing, screen and gravel will be inspected by the New Mexico State University representative before it is placed in the well. State Engineer's representative will also inspect the casing and screen as well as cementing operation and pump testing. A 20 minute hydrostatic test under a minimum test pressure of $200 \mathrm{psi}$ at the surface shall be performed by the contractor under the direction and to the satisfaction of a representative of the State Engineer.

Final Site Condition

The contractor will leave the top of the casing 4 feet above the ground level with a plate welded to the top.

The well site will be left clean and all tools and trash removed from the well site when the contractor removes the rig.

Drillers Log

The driller shall keep a log indicating time, depth, significant activities performed, observations, etc. A copy of this $10 g$ will be supplied to New Mexico State University. 


\section{Possible Cost-Cutting Modifications}

As a result of financial considerations, the university may decide to eliminate the installation of a 2-inch PVC pipe and resulting 24 hour wait for a temperature $10 \mathrm{~g}$. If this option is followed, the geophysical logging will be done within a reasonable time after the drilling and the driller can then proceed with ordering and installing the screen and casing.

\section{Reference Cited}

Theis, C.V., et. al. (1941), Thermal waters of the Hot Springs artesian basin, Sierra Country, New Mexico, in 14th and 15th Biennial Reports, New Mexico State Engineer, pp. 421-286. 


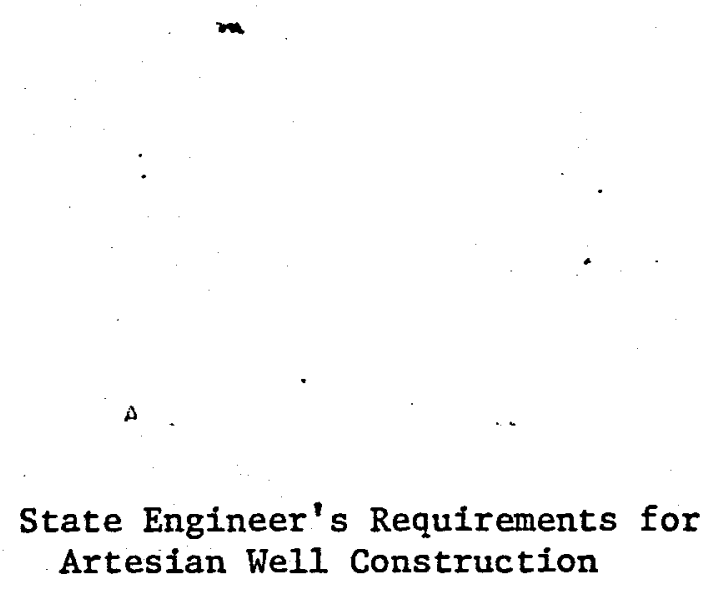


FROM STATE ENGINEER, DEMING OFFICE

4-15. ARTESIAN WELLS--CONSTRUCTION. The casing for aretsian wells shall be inspected by the State Engineer or his representative and shall meet or exceed the specifications as set forth in 4-15.1. All casing and collars must be in good condition. A standard casing shoe shall be used in all instances. The casing shall not be perforated in a manner that would allow the commingling of water from the artesian formation with water in overlying formations.

(OVER) 
4-15.1 CASING AND COUPLING: API TABLE OF SPECIFICATIONS.

only threaded casing shall be used. Casings and couplings shall meet minimum American Petroleum Institute (API) specifications for the following sizes:

\begin{tabular}{|c|c|c|c|c|c|c|}
\hline \multirow{2}{*}{$\begin{array}{l}\text { Outside } \\
\text { Diameter } \\
\text { Inches }\end{array}$} & \multirow{2}{*}{$\begin{array}{c}\text { Weight } \\
\text { with } \\
\text { Couplings } \\
\text { lbs./ft. }\end{array}$} & \multirow{2}{*}{$\begin{array}{l}\text { Wall } \\
\text { Thickness } \\
\text { Inches } \\
\text {. }\end{array}$} & \multicolumn{3}{|c|}{ Coupling } & \multirow[b]{2}{*}{$\begin{array}{c}\text { Grade } \\
\text { of } \\
\text { Casing }\end{array}$} \\
\hline & & & $\begin{array}{l}\text { O.D. } \\
\text { Inches }\end{array}$ & $\begin{array}{l}\text { Length } \\
\text { Inches }\end{array}$ & $\begin{array}{c}\text { Threads } \\
\text { per } \\
\text { Inch } \\
\end{array}$ & \\
\hline & & $m$ & & & & \\
\hline $41 / 2$ & 9.50 & .205 & 5.000 & 5 & 8 & $F-25$ \\
\hline $51 / 2$ & 13.00 & .228 & 6.050 & $63 / 4$ & 8 & $F-25$ \\
\hline 6 & 15.00 & .238 & 6.625 & 7 & 8 & $F-25$ \\
\hline $65 / 8$ & 17.00 & .245 & 7.390 & $71 / 4$ & 8 & $F-25$ \\
\hline 7 & 17.00 & .231 & 7.656 & $71 / 4$ & 8 & $F-25$ \\
\hline $75 / 8$ & 20.00 & .250 & 8.500 & $71 / 2$ & 8 & $F-25$ \\
\hline $85 / 8$ & 24.00 & .264 & 9.625 & $73 / 4$ & 8 & $F-25$ \\
\hline $95 / 8$ & 29.30 & .281 & 10.625 & $73 / 4$ & 8 & $F-25$ \\
\hline $103 / 4$ & 32.75 & .279 & 11.750, & 8 & 8 & F-25 \\
\hline $113 / 4$ & 38.00 & .300 & 12.750 & 8 & 8 & $F-25$ \\
\hline $133 / 8$ & 48.00 & .330 & 14.375 & 8 & 8 & $F-25$ \\
\hline
\end{tabular}

If casing length exceeds one thousand $(1,000)$ feet, H-grade or better shall be used for thirteen and three-eighths $(133 / 8)$-inch casing.

$\checkmark$ 4-15.2 HOLE DIAMETER. In all cases the diameter of the drilled hole shall be at least two (2) inches greater than the outside diameter of the casing.

4-16. CASING: CEMENTING; TESTING. The following specificatlons shall govern casing, cementing, and testing: The casing shoe shall be welded to the casing to assure proper position. The casing snall be landed on a suitable casing seat in the confining formation 
overlying the artesian aquifer formation and sufficient oil well cement shall be used to obtain circulation to the surface. When circulation to the surface is not obtained, cement shall be placed to the surface behind the casıng. Additives of pozzolanic nature may be used above the casing shoe but shall not exceed fifty (50) per cent by volume. The addition of calcium chloride and/or gel is permissible but shall not in any case exceed two (2) per cent each by weight. A sufficient amount of cement without additives shall be used to allow neat cement to seal the casing shos and rise a minimum of fifty (50) feet above the shoe between the casing and the hole. Cement shall be allowed to set a minzmum of fortyeight (48) hours before drilling is resumed. Sealing off of the the formations shall be checked by a method approved by the state Engineer or his authorized representative.

4-16.1 CEMENTING. Cementing shall be done by the pump and plug method as follows: After the casing has been run and landed, the pump shall be started and mud circulation shall be maintained for at least thirty (30) minutes with the casing raised slightly in order to equalize the mud pressure inside and outside of the casing. A heavy slurry of oil well cement and water shall be mixed and poured into the top of the casing. If additives are used in the slurry, sufficient neat cement (density fifteen (15) pounds per gallonl shall then be added to seal the casing shoe 
and rise a minimum of fifty (50) feet above the shoe. A caring plug of standard make shall be placed in the casing above the cement and a swedge nipple screwed onto the top of the casing and connected to the mud pump. Then a mud slurry or water shall be pumped into the casing, forcing the cement and casing plug down the casing. A measuring line shall be run behind the plug so that the driller may know its location at all times. When the plug reaches the point desired above the bottom of the casing. the pump shall be stopped and the casing lowered to the casing seat.

4-17. CASING, CEMENTING, TESTING--APPROVAL. The casing, cementing, and testing programs shall be witnessed and approved by an authorized representative of the state Engineer.

4-18. EXCEPTION TO CASIRG AND CEMENTING REQUIREMENTS. In those areas of declared artesian basins where the well is drilled into the artesian aquifer, but no confining formation overlying the artesian formation is present, the foregoing requirements for casing and cementing are not applicable and may be altered by receiving written approval of the state Engineer or his representative.

4-19. ARTESIAN WELLS--REPAIR. Before repairs are comenced the well shall first be inspected by a representative of the state Engineer to determine if the condition of the well is such that it may be repaired. When leaks in the casing are found and the casing 
and well are otherwise in good condition, the well may be repaired by a method approved by the state Engineer, A packer or bridge plug approved by the state Engineer shall be used in all well repairs. An inspection shall be made at the completion of the work to determine if the repair was satisfactory. During each inspection, the hole shall be open to allow the entrance of equipment for well logging and leakage measurement. 4-19.1 PLUGGING. If an artesian well is to be replaced by a new well. it shall be plugged immediately following the completion of the new well. All the work shall be done under the supervision of. the state Engineer or his representatives or a representative of the appropriate Artesian Conservancy District who shall designate the amount of cement to be used and the depths at which cement plugs shall be set.

4-20. TEST OR EXPLORATORY WELLS. AII test or exploratory wells shall be so constructed, maintained, and operated that each water shall be confined to the aquifer in which it is encountered. All test or exploratory wells penetrating artesian aquifers shall be cased, cemented, and tested as required for the construction of artesian wells (Article 4-15 through 4-18) and the casing shall be landed in the formation underlying the deepest artesian aquifer and cemented through all known artesian aquifers. The casing, as referred to in the artesian well specifications, is designated as 
the water protection string by the oil industry. If conductor pipe is used, it shall not be removed until after cementing of the casing has been completed. All casing, cementing, and testing programs shall be witnessed and approved by a representative of the State Engineer.

4-20.1 SHOTHOLES--PENETRATION. Shotholes for geophysical exploration shall not penetrate closer than twenty-five (25) feet above any known artesian aquifer under confinement.

4-20.2 ABANDONMENT; PLUGGING. In the event that the test or exploratory well is to be abandoned, the state Engineer shall be notified. Such well shall be plugged in accordance with Article 4-19.1 so that the fluids wili be permanently confined to the specific strata in which they were originally encountered.

4-21. MINE LODE DISCOVERY AND DRILL HOLES. ANY person drilling a mine lode discovery or mine drill hole to a depth of ten (10) feet or more, who shall encounter or whose drill shall cut into a water body or water bearing strata, shall plug or otherwise construct, maintain, and operate such holes so that any water encountered is permanently confined to the aquifer in which it is found.

4-21.1 DISCOVERY REPORT-FORMS; TIME FOR FILING. Such persOn, within ninety (90) days from the date of the discovery. shall report to the State Engineer, on forms provided by the state 
Engineer, the location and depth of the hole, and the method and material used in plugging the hole. If the hole is not plugged. the report shall describe the manner in which it was constructed and is being maintained and operated. The report shall include a $\log$ of the hole which is adequate to permit a determination of whether the plugging or construction and operation and maintenance of the drill hole are satisfactory.

4-21.2 ARTESIAN WATER. If artesian water is encountered, the construction, operation, maintenance, or plugging shall be done in accordance with Article 4-15 through 4-19.1.

4-22. DEVIATIONS FROM SPECIFICATIONS--APPROVAL. ANY deVIations from the above-described casing, cementing, and testing programs must be approved by the state Engineer. 
Negotiated

TECHNICAL SPECIFICATIONS

1. Drill a $12-1 / 4$ inch diameter well to 100 feet.

2. Allow geophysical logging of the well by a logging contractor to be hired by MMSU.

3. Install 8 inch diameter I.D. threaded and coupled surface casing of grade F-25 with 24 lbs/ft weight with couplings to a depth of $100 \mathrm{ft}$. The casing and couplings should meet the standards specified by the State Engineer and should be approved by a representative from the State Engineer's office before installation.

4. Cement the surface casing according to methods approved by the State Engineer and allow the cement to set for at least 48 hours.

5. Perform a hydrostatic pressure test at a minimum of 200 psi pressure at the surface for a duration of at least 20 minutes, according to State Engineer's specifications. This test should be conducted in the presence of the State Engineer's representative and his approval obtained.

6. Drill a minimum of $6-3 / 4$ inch diameter production well to a depth of 250 feet.

7. Order and install 5 inch I.D. stainless steel casing and screen. The lengths and locations of the screen and casing will be determined by the New Mexico State University representative on the basis of geophysical and 1ithologic logs.

8. Develop the well for at least 10 hours or until clear water is obtained.

The contractor is to be paid according to the following schedule:

\begin{abstract}
Mobilization
$100 \mathrm{ft}$. drilling

Surface casing

Cementing

Production casing

Production screen

Well development
\end{abstract}

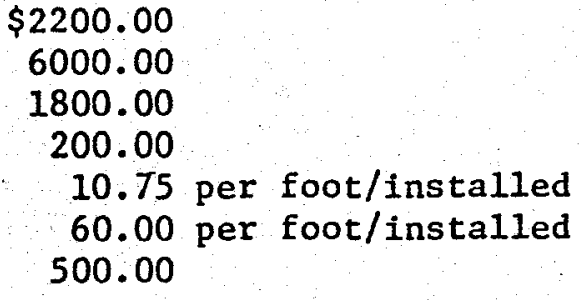


The contract to the driller should mention two items specifically:

1. The driller is responsible for keeping the State Engineer's Office in Deming informed about his schedule of drilling. He should drill the well according to the State Engineer's specifications for cementing, pressure testing and the quality of casing, etc.

2. The contract is for the entire job as specified in the Purchase Order. Partial completion of the work will not automatically entitle the driller to proportionate payment.

3. The total cost of the project is not to exceed $\$ 19,800.00$. 


\begin{tabular}{|l|l|l|}
\hline O. OF COPIES RECEIVED & & \\
\hline DISTRIBUTION & & \\
\hline ie & & \\
\hline S.o.s. & & \\
\hline serator & & \\
\hline ind Olfice & & \\
\hline
\end{tabular}

NEW MEXICO OIL CONSERVATION COMMISSION P. O. Box 2088, Santa Fe 87501

APPLICATION FOR PERMIT TO DRILL, DEEPEN, OR PLUG BACK...GEOTHERMAL RESOURCES WELL
.. Type of Work

Drill $D$

Deepen

$\square$

Geothermal Producer $\triangle$

Low-Temp Thermal
Plug Back

Temp Observation Injection/Disposal

Name of Operator

New Mexico State University/City of $\mathrm{T}$ or $\mathrm{C}$

Address of Operator Dr. Lokesh Chaturved1 - Co. P.I.

Box 3CE, NMSU, Las Cruces, NM 88003

Location of Well

UNIT LETTER _ 0 LOCATED 500
FEET FROM THE SOUth CLINE

2300

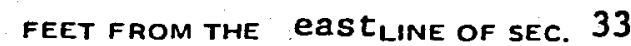
TwP. 1 3 south $_{\text {RGE. } 4 \text { west }}$ NMPA

17.

$\$$ . Hevations / Show whether DF. RT, etc.)

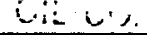
\begin{tabular}{l|l}
$2 i$. Kind \& Stasus Plug. Bond \\
Waiver requested
\end{tabular} SMIIIA FE

\section{PROPOSED CASING AND CEMENT PROGRAM}

19A. For... Magdal ena 1, lit:s tcone i20. Kotary or C.T. $500 \mathrm{ft}$.

21B. Drilling Contractor to be selected

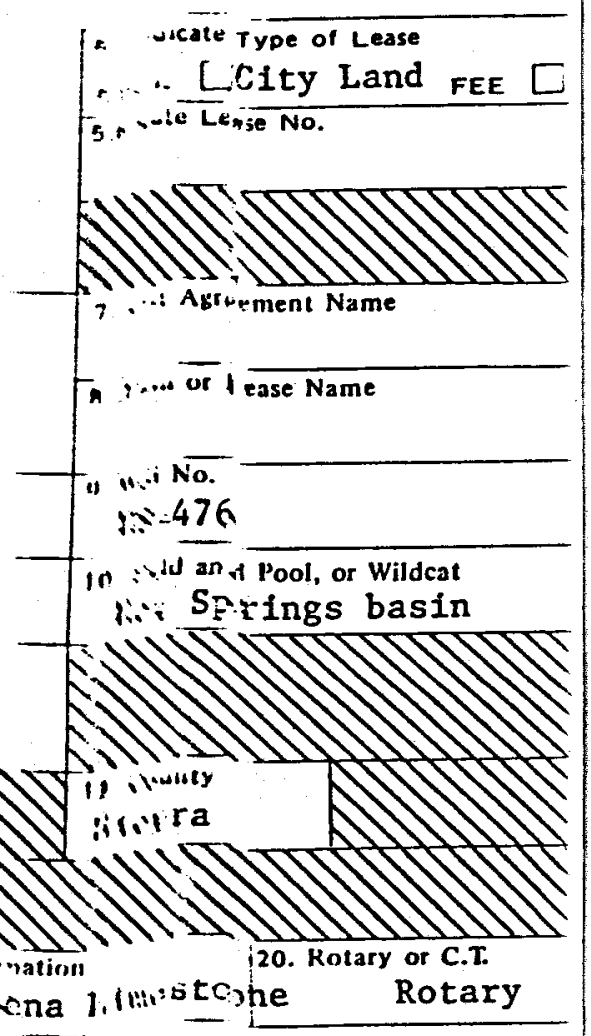

1

IVFG' Pate Work will start

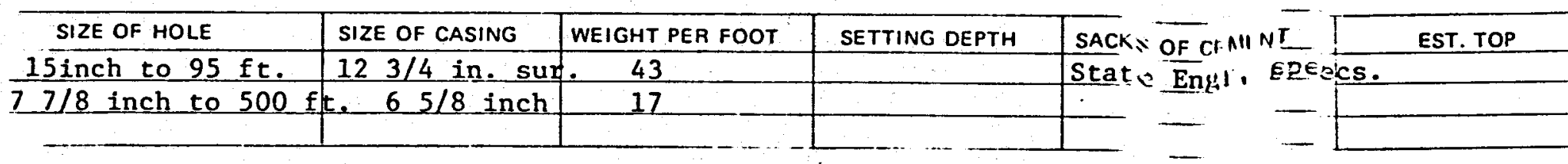

A permit from the State Engineer for 30 acre feet per annum has buen roinfyeod. The well will be drilled by a licensed driller according to the State Englimir specifications. The State Engineer requirements for inspection, testing, etc. will be mil, The depth and length of screen installation will be determined on the basis of ginll. $z$ sical and lithologic well logs. Request waiving the bond requirements for Mlugglll! since it is a production well. This is a part of a research project funded by N.M. lis.er.agy and Minerals Department.

Bond No. 01-0130-3:10-8 $\quad$ r. $\leqslant \tau=$ ed

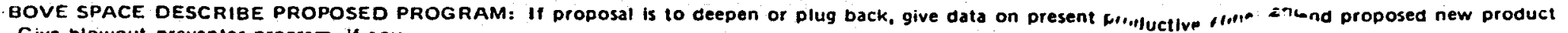
Give blowout preventer program, if any.

thv certify that the information above is true and complete to the best of my knowledge and belief.

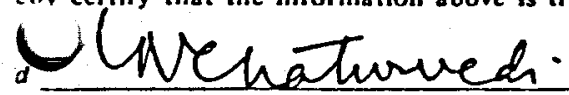

Tille Associate Professor, NMSU

(This space for Srate Use)

$\stackrel{\text { Dase }}{=} / 1 \%=180$

zoved ar Caul Lleurg

DITIONS OF APPROVAL, IF ANY: TITLE

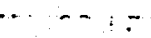

$\cdots \cdots+\cdots \cdots+\cdots$ i DATI

$--3-\overline{8} 0$ 
All distances must be from the outer boundaries of the Section.

\begin{tabular}{l|l|l}
\hline $\begin{array}{c}\text { Operatur } \\
\text { New Mexico State University/City of } T \text { or } C\end{array} \quad$ City land & $\begin{array}{c}\text { Well No. } \\
\text { HS }-476\end{array}$ \\
\hline
\end{tabular}

\begin{tabular}{|l|l|l|l|l|l|} 
Letter & Section 33 & $\begin{array}{c}\text { Township } \\
13\end{array}$ & South & 4 West & Sierra \\
\hline
\end{tabular}

Actual Footage Location of Well:

2300

feet from the

east

line and 500

feet from the

south

Producing Formation
lagdalena Limestone

Pool

1. Outline the acreage dedicated to the subject. well by colored pencil or hachure marks on the plat below.

2. If more than one lease is dedicated to the well, outline each and identify the ownership thereof (both as to working interest and royalty).

3. If more than one lease of different ownersip is dedicated to the well, have the interests of all owners been consolidated by communitization, unitization, force-pooling, etc?

Yes $\square$ No If answer is "yes," type of consolidation

If answer is "no," list the owners and tract descriptions which have actually been consolidated. (Use reverse side of this form if necessary.)

No allowable will be assigned to the well until all interests have been consolidated (by communitization, unitization, forced-pooling, or otherwise) or until a non-standard unit, eliminating such interests, has been approved by the Commission.

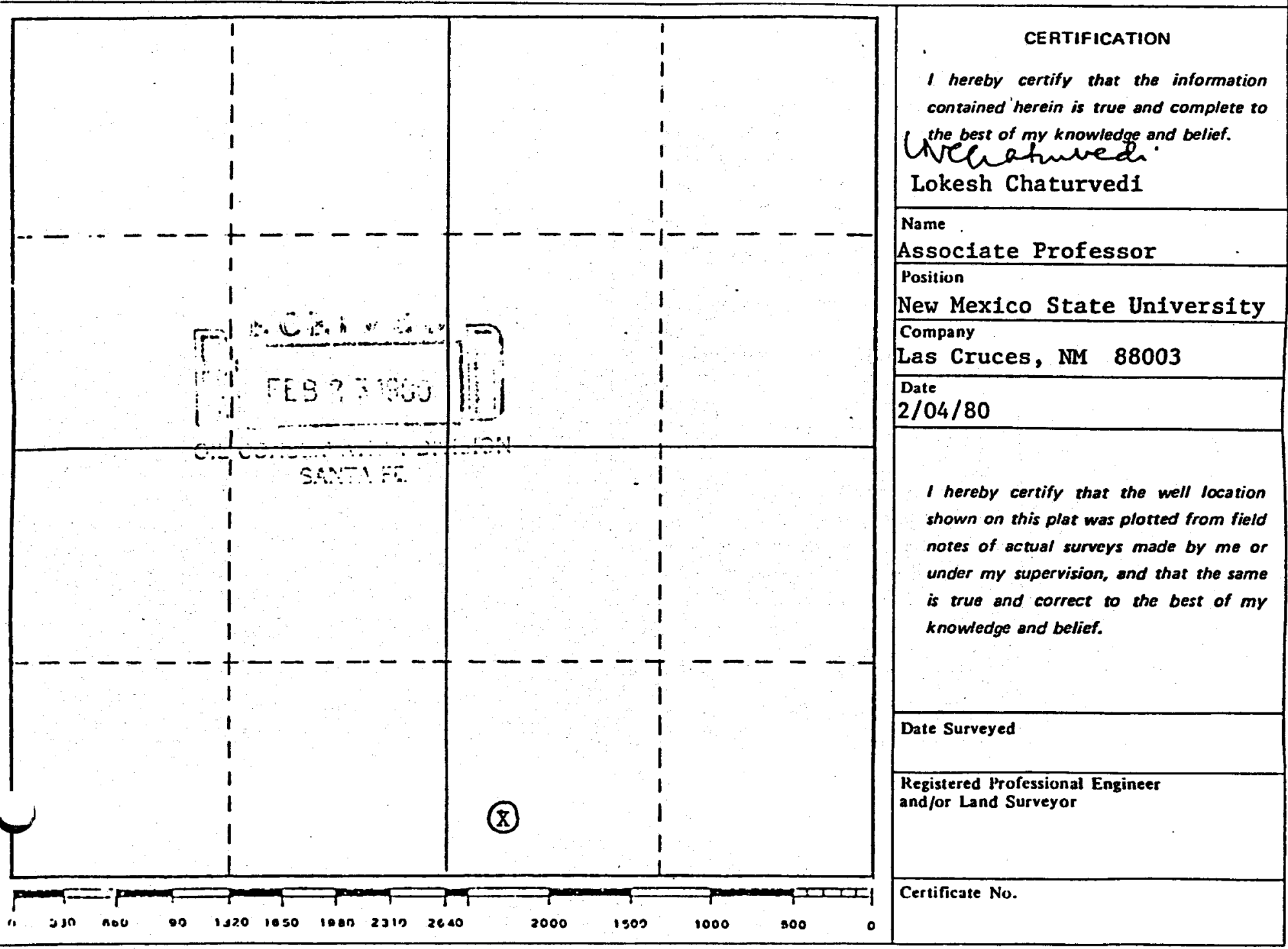




$$
\text { DistribuTION }
$$

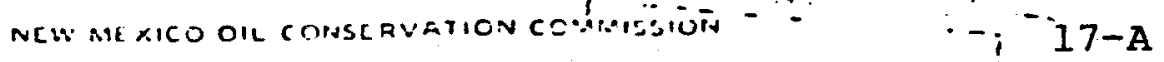

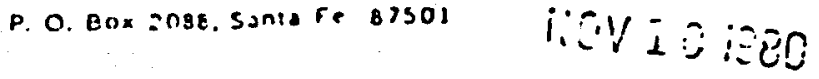

\begin{tabular}{|l|l|l|}
\hline B.M. & 1 & 1 \\
\hline 5 & 1 & 1 \\
\hline Online & 1 & 1 \\
\hline
\end{tabular}

SUNDRY NOTICES AND REPORTS; ON

GEOTHERMAL RESOURCES WELLS

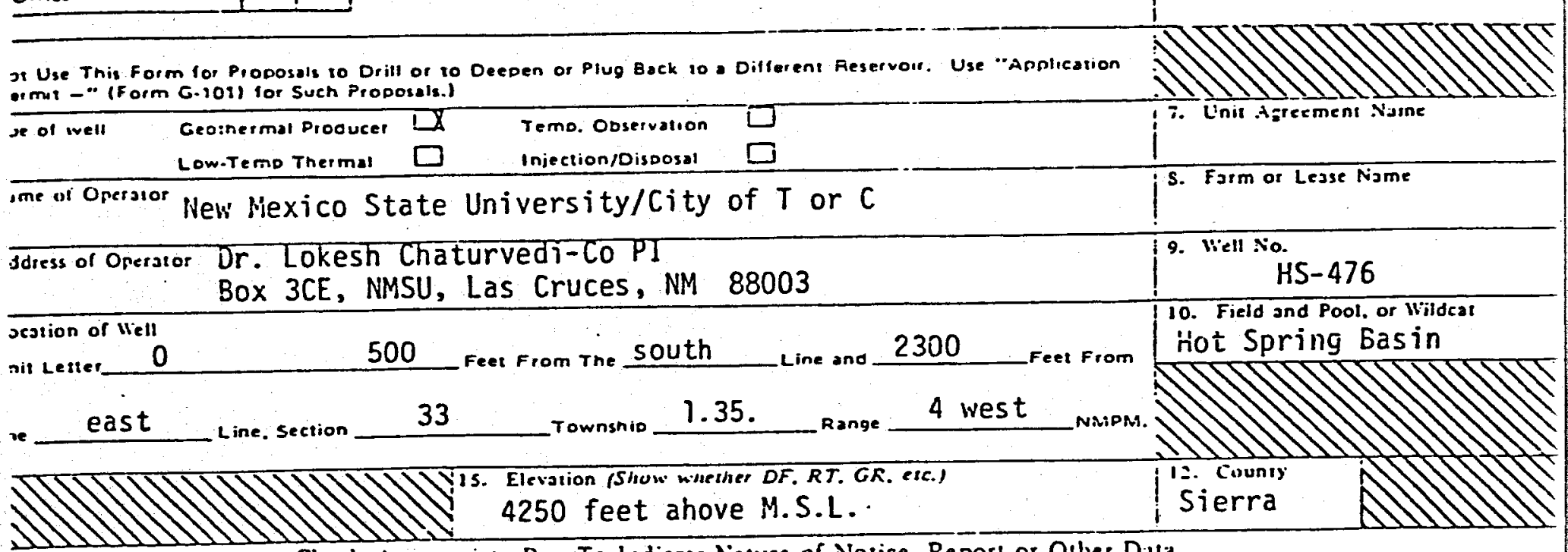

Check Appropriate Box To Indicate Nature of Notice. Re port or Other Data

NOTICE OF INTENTION TO:

ORE REMEDIAL WORK - ORARILY AbANDON

OR ALTER CASING
PLUG and abaNdon

change plans
SUESEOUENT REPORT OF:

REMEDIAL WORK COMANENCE DRILLING OPTS. CASING TEST AND CEMENT JOB
ALTERING CASING

PLUG \& ABANDONMENT

OTHER

THE

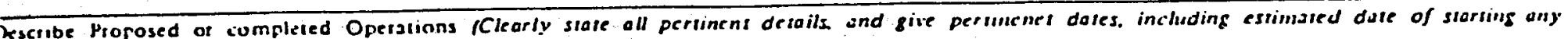
reposed Work, SEE RULE 203.

Please see the enclosed letter and new specifications for the well

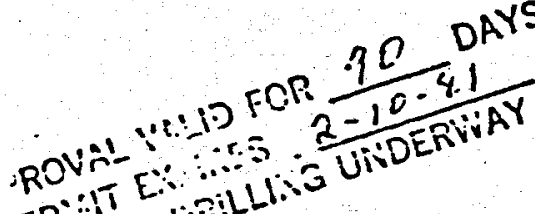

OIL CONSERVATOr

UNLESS URILLIVS UTE WITHIN 24 HOUND OF LIE

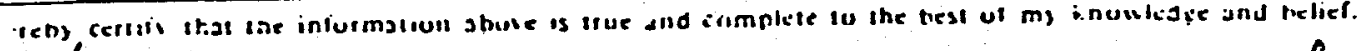

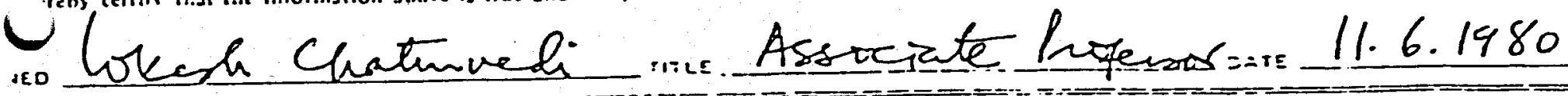

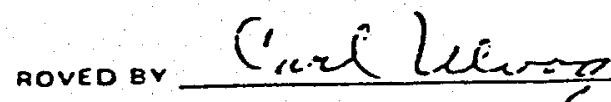

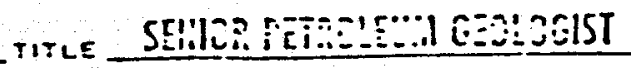
SATE $11-12-80$

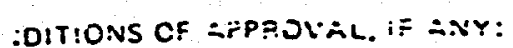




\begin{tabular}{|l|l|l|}
\hline OF COPIES RECEIVED & \\
\hline OISTRIBUTION & & \\
\hline IE & & \\
\hline and Office & & \\
\hline and & & \\
\hline
\end{tabular}

NEW MEXICO OIL CONSERVATION COMMISSION

P. O. Box 2088, Santa Fe 87501

SUNDRY NOTICES AND REPORTS

ON

GEOTHERMAL RESOURCES WELLS

'o Not Use This Form for Proposals to Drill or to Deepen or Plug Back to a Different Reservoir. Use "Application or Permit - (Form G-101) for Such Proposals.)

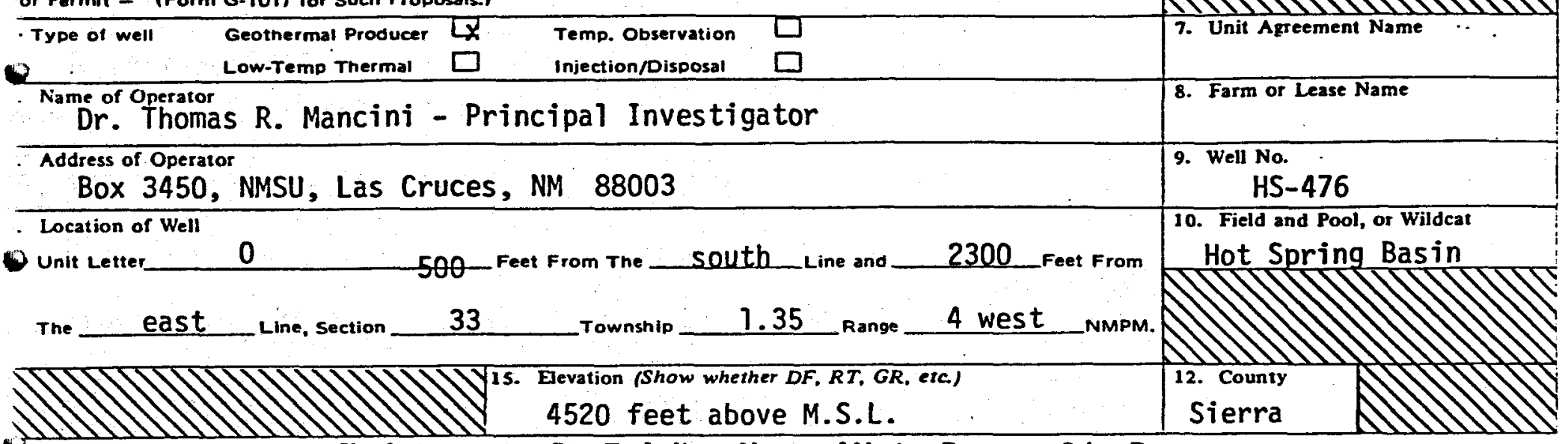

Q.

Check Appropriate Box To Indicate Nature of Notice, Report or Other Data

NOTICE OF INTENTION TO:

טו

JERFORM REMEDIAL WORK $\square$

-EMPORARILY ABANDON plug AND abandon

CHANGE PLANS

SUBSEOUENT REPORT OF:

5. Indicate Type of Lease state $\square$ city landee $\square$ 5.a State Lease No.

OTHER

7. Describe Proposed or completed Operations fClearly state all pertinent details and give pertinenet dates, including estimated date of starting any proposed work/ SEE RULE 203.

The well was drilled to a total depth of 250 feet. The anticipated geothermal resource was not found. The well was then filled with cement and the ground returned to its original condition. This action was completed on September 30, 1981. The State Engineer's representative, Mr. Putnam from the Deming office, has examined the site after this operation.

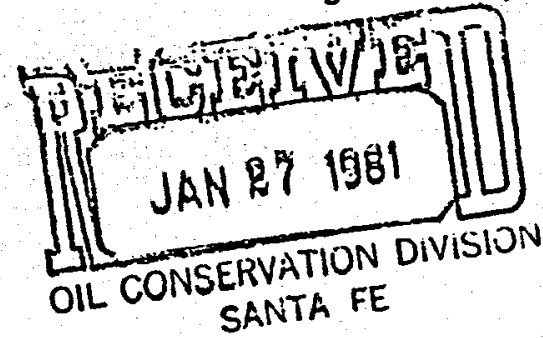

18. preby certify the information above is true and complete to the best of my knowledge and belief.

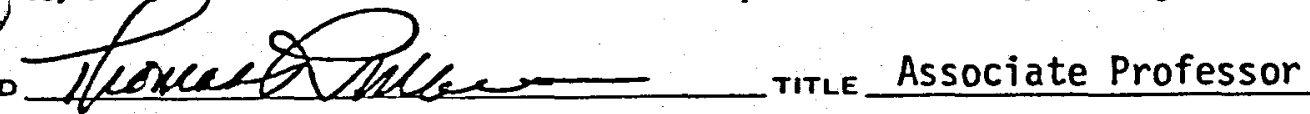

APPROVED BY

DATE $17 \operatorname{tach} 1982$

CONINITIONE OF APPROVAL. IF ANY 


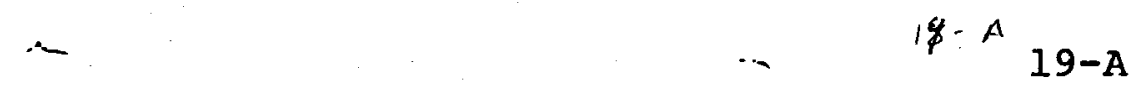

WR -20

Deming

State Engineer

$10 / 65$

$\operatorname{March~} 13 \ldots$

716. City of Truth or Consequences

605 Sims

Truth or Consequences, New Mexico

87901

bxy Gent lemen

The following notice shall be published at applicant's expense once a week for three (3) consecutive weeks in a newspaper of general circulation in the stream system, or in case of an underground water appropriation the County wherein the well is to be drilled. First publication should be made as soon as possible after receipt of this notice. Publisher's affidavit of such publication must be filed with the State Engineer within sirty $(60)$ days from the date hereon. If the application is for a new appiopriation, failure to file proof of publication within the time allowed shall cause postponement of the priority date of the application to the date of receipt of such proof in proper form. In the case of any other type of application, failure to file proofs within the time allowed will cause the application to be cancelled.

The accuracy as to the content of this Notice is the responsibility of the applicant and the State Engineer is not obli: $g^{a t e d}$ for any additional expense incurred by the necessity of readveyisemegt. Neither issuance of this Notice, nor lack of protest thereto, in apy way indifpres favorable action by the State Engineer
or approval of the application as requested.

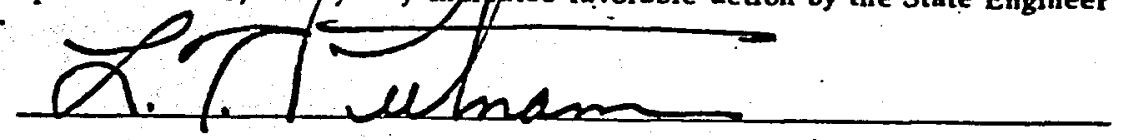

L. T. Putnam, Supervisor, District III

NOTE TO PUBLISHER: Immediately afier last publication, publisher is requested to file affidavlt of such publicatlon with the State Engineer, P. P. Box 844 Deming New Mexico. 88030

Notice is hereby given that on March 12, 1979, City of Truth or Consequences, Quentin M. Drunzer, City Manager, 605 Sims, Truth or Consequences, New Hexico 87901

filed application (o) number (et)

IIS -476

with the STATE ENGINEER for permit (8) to appropriate 30 acre feet of artesian thermal waters of the liot Springs Underground Water Basin by drilling an artesian we11 7.5 inches in diameter and approximately 500 feet deep, to be located in the $S^{\frac{1}{4}} S^{1} \frac{1}{4} S^{\frac{1}{2}}$ of Section 33, Township 13 South, Range 4 West, N.M.P.M.; water to be used for geothermal space heating in the Senior Citizen's Center in the City of Truth or Consequences, New Mexico.

The applicant states: "The project has been approved for funding by the New Mexico Energy and Minerals Department under State Geothermal Demonstration Program, 1979." 


\section{Application for Permit to Change Location of Well}

Date Received

File No. HS-476 into HS-24

1. Name of Water Right Owner City of Truth or Consequences, Quentin Drunzer, City Manager Street or Post Offico Address 605 Sims Street

City and State Truth or Consequences, New Mexico

Zip Code $\quad 87901$

2. Source of water supply artesian -water aquifer . located in Hot Springs Underground Water Basin (artesian or shallow water aquifer)

(name of underground basin)

3. Well from which rights are to be severed:
(a) Well is in the SW $1 / 2$ SW $\%$
or Tract No. of Map No.
SE $\%$. Section of the Range $4 \mathrm{~W}$
N.M.P.M.,
(b) Is well to be plugged
Yes : If not, state for what use retained

4. Application is made to change location of well for the following reasons (If well is to be used for only a part of original right describe that part by legal description under item number 6): well No. HS-476 was a dry hole after completion and was plugged

5. Well to which transfer is to be made:
(a) Located in the
SW $1 \%$ SW $1 / 4$ SE $1 / 4$, Section 33 Township 13S Range 4N N.M.P.M., or Tract No. of Map No. of the
on land owned by City of Truth or Consequences
(b) Quantity of water to be appropriated See Item 136 below acre feet applied to acres of land; if not for irrigation, specify purpose_ Geothermal space heating
(c) If existing well, give File No. HS-24
(d) If a new well, give name of driller
(e) Outside diameter of casing inches; Approximate depth to be drilled feet.

6. Additional statements or explanations For the appropriation of shallow groundwater not to exceed 30.0 acre-feet per annum measured at the well for geothermal space heating in the Senior Citizens Center and related purposes located in Part SE $\frac{1}{4}$ of Section 33, Township 13 Seuth, Bange 4 West

1. Quentin M. Drunzer and belief and that $\mathrm{I}$ am the affirm that the foregoing statements are true to the best of my knowledge agent for owner and holder of said water right. (sole, partial, agent for, etc.)

CITY OF TRUTH OR CONSEQUENCES , Applicant

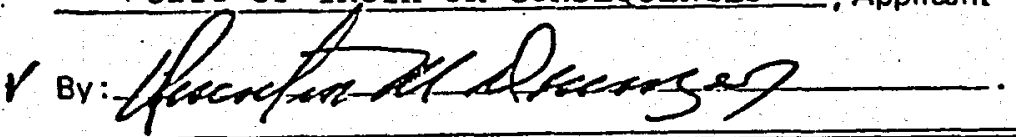

\section{ACTION OF STATE ENGINEER}

After notice pursuant to statute and by authority vested in me, this application is approved provided it is not exercised to the impairment of any others having existing rights: further provided that all rules and regulations of the State

Engineser pertaining to the drilling of wells be complied with; and further subject to the following conditions: 


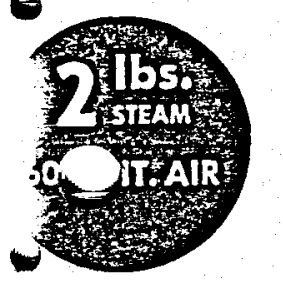

\title{
steam performance data
}

\author{
standard models at standard conditions
}

\section{GH MOTOR SPEEDS}

\begin{tabular}{|c|c|c|c|c|c|c|c|c|c|c|c|}
\hline \multirow{2}{*}{ 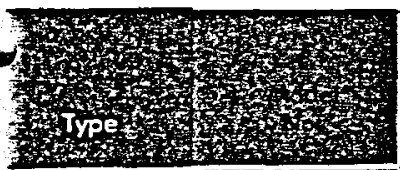 } & \multirow{2}{*}{ 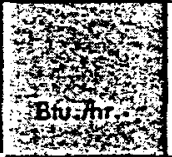 } & \multirow[b]{2}{*}{$\begin{array}{l}\text { Sq. Ft. } \\
\text { Edr. }\end{array}$} & \multirow[b]{2}{*}{$\begin{array}{l}\text { Sound } \\
\text { Class }\end{array}$} & \multicolumn{6}{|c|}{ AIR DATA } & \multicolumn{2}{|c|}{ MOTOR DATA } \\
\hline & & & & $\begin{array}{l}\text { Max. } \\
\text { Mounting } \\
\text { Height } \\
\text { (ft.) }\end{array}$ & $\begin{array}{c}\text { Heat } \\
\text { Throw or } \\
\text { Spread } \\
\text { (ft.) }\end{array}$ & tCfm. & $\begin{array}{l}\text { Outlet } \\
\text { Velocity } \\
\text { (Fpm.) }\end{array}$ & $\begin{array}{c}\text { Final } \\
\text { Air } \\
\text { Temp. } \\
\text { (F) }\end{array}$ & $\begin{array}{c}\text { Conden- } \\
\text { sate } \\
\text { Lbs./hr. }\end{array}$ & $H$ & $\begin{array}{c}\text { Approx. } \\
\text { Rpm. }\end{array}$ \\
\hline 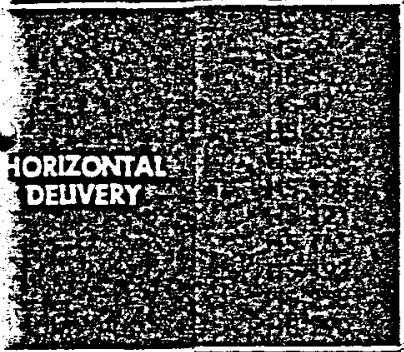 & 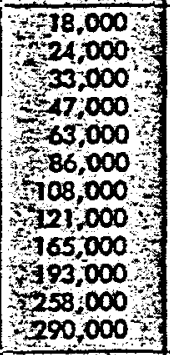 & $\begin{array}{r}75 \\
100 \\
138 \\
196 \\
263 \\
358 \\
450 \\
504 \\
688 \\
804 \\
1075 \\
1208\end{array}$ & $\begin{array}{l}\text { II } \\
\text { II } \\
\text { III } \\
\text { II } \\
\text { III } \\
\text { III } \\
\text { III } \\
\text { IV } \\
\text { IV } \\
\text { V } \\
\text { V }\end{array}$ & $\begin{array}{l}8 \\
9 \\
10 \\
12 \\
14 \\
15 \\
17 \\
16 \\
19 \\
18 \\
19 \\
20\end{array}$ & $\begin{array}{l}17 \\
18 \\
21 \\
28 \\
29 \\
31 \\
31 \\
25 \\
40 \\
38 \\
44 \\
46 \\
\end{array}$ & $\begin{array}{r}340 \\
370 \\
630 \\
730 \\
1,120 \\
1,340 \\
2,010 \\
1,775 \\
3,240 \\
2,900 \\
4,560 \\
4,590 \\
\end{array}$ & $\begin{array}{l}625 \\
695 \\
690 \\
810 \\
690 \\
835 \\
790 \\
715 \\
880 \\
810 \\
750 \\
765 \\
\end{array}$ & $\begin{array}{l}107 \\
119 \\
108 \\
119 \\
111 \\
118 \\
109 \\
122 \\
106 \\
121 \\
111 \\
117 \\
\end{array}$ & $\begin{array}{r}18 \\
25 \\
35 \\
49 \\
66 \\
89 \\
111 \\
126 \\
170 \\
200 \\
267 \\
300\end{array}$ & $\begin{array}{c}16 \mathrm{MHP} \\
1 / 25 \\
1 / 25 \\
1 / 12 \\
1 / 12 \\
1 / 6 \\
1 / 8 \\
1 / 6 \\
1 / 3 \\
1 / 3 \\
1 / 2 \\
1 / 2\end{array}$ & $\begin{array}{l}1550 \\
1550 \\
1550 \\
1550 \\
1550 \\
1625 \\
1625 \\
1075 \\
1075 \\
1075 \\
1075 \\
1075\end{array}$ \\
\hline 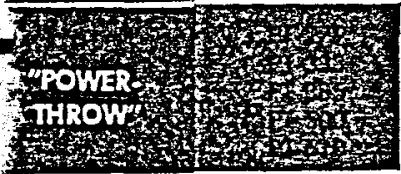 & $\begin{array}{l}7279,000 \\
333,000 \\
335,000 \\
500,000 \\
610,000\end{array}$ & $\begin{array}{l}1163 \\
1388 \\
1604 \\
2083 \\
2542\end{array}$ & $\begin{array}{l}\mathbf{V} \\
\mathbf{V} \\
\mathbf{V} \\
\mathbf{V} \\
\mathbf{V}\end{array}$ & $\begin{array}{l}16 \\
17 \\
17 \\
18 \\
20\end{array}$ & $\begin{array}{l}100 \\
108 \\
115 \\
128 \\
140\end{array}$ & $\begin{array}{r}5,460 \\
5,980 \\
7,680 \\
10,390 \\
11,750\end{array}$ & $\begin{array}{l}2165 \\
2165 \\
1860 \\
2520 \\
2315\end{array}$ & $\begin{array}{l}111 \\
116 \\
110 \\
108 \\
112\end{array}$ & $\begin{array}{l}288 \\
345 \\
398 \\
518 \\
631\end{array}$ & $\begin{array}{l}1 / 2 \\
3 / 4 \\
1 \\
11 / 2 \\
11 / 2\end{array}$ & $\begin{array}{l}1075 \\
1140 \\
1140 \\
1140 \\
1140\end{array}$ \\
\hline 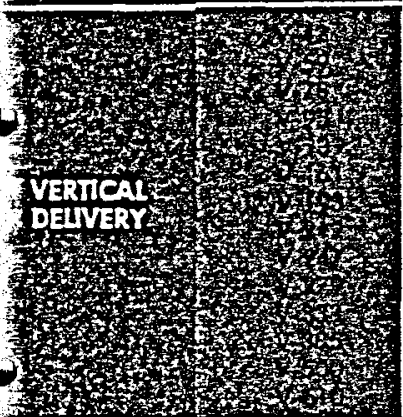 & 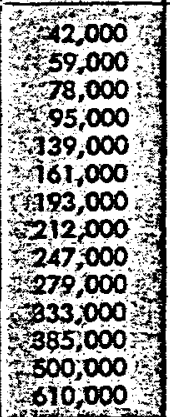 & $\begin{array}{l}175 \\
246 \\
325 \\
396 \\
579 \\
671 \\
804 \\
883 \\
1029 \\
1163 \\
1388 \\
1604 \\
2083 \\
2542\end{array}$ & $\begin{array}{l}\text { II } \\
\text { II } \\
\text { II } \\
\text { II } \\
\text { III } \\
\text { IV } \\
\text { IV } \\
\text { IV } \\
\text { V } \\
\text { V } \\
\text { V } \\
\text { VI } \\
\text { VI } \\
\text { VI }\end{array}$ & $\begin{array}{l}15 \\
19 \\
20 \\
20 \\
24 \\
27 \\
30 \\
30 \\
34 \\
37 \\
37 \\
36 \\
44 \\
43\end{array}$ & $\begin{array}{l}11 \\
14 \\
15 \\
15 \\
18 \\
20 \\
22 \\
22 \\
26 \\
30 \\
30 \\
30 \\
37 \\
36\end{array}$ & $\begin{array}{r}950 \\
1,155 \\
1,590 \\
1,665 \\
2,660 \\
2,945 \\
3,500 \\
3,610 \\
4,820 \\
5,460 \\
5,980 \\
7,680 \\
10,390 \\
11,750\end{array}$ & $\begin{array}{l}825 \\
1005 \\
1065 \\
1120 \\
1285 \\
1420 \\
1690 \\
1740 \\
1910 \\
2165 \\
2165 \\
1860 \\
2520 \\
2315\end{array}$ & $\begin{array}{l}103 \\
111 \\
109 \\
118 \\
112 \\
115 \\
116 \\
120 \\
111 \\
111 \\
116 \\
110 \\
108 \\
112\end{array}$ & $\begin{array}{r}43 \\
61 \\
81 \\
99 \\
144 \\
167 \\
200 \\
219 \\
256 \\
288 \\
345 \\
398 \\
518 \\
631\end{array}$ & $\begin{array}{l}1 / 30 \\
1 / 30 \\
1 / 15 \\
1 / 13 \\
1 / 6 \\
1 / 3 \\
1 / 3 \\
1 / 3 \\
1 / 2 \\
1 / 2 \\
3 / 4 \\
1 \\
11 / 2 \\
11 / 2\end{array}$ & $\begin{array}{l}1050 \\
1050 \\
1050 \\
1050 \\
1075 \\
1075 \\
1075 \\
1075 \\
1075 \\
1075 \\
1140 \\
1140 \\
1140 \\
1140\end{array}$ \\
\hline
\end{tabular}

\section{EDUCED MOTOR SPEEDS}

?quires solid state motor speed controller

\begin{tabular}{|c|c|c|c|c|c|c|c|c|c|c|c|}
\hline 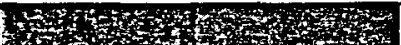 & ats & & & & & AIR & ATA & & & MOT & DATA \\
\hline 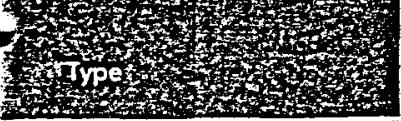 & 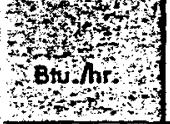 & $\underset{\text { Edr. }}{\text { Sq. Ft. }}$ & $\begin{array}{l}\text { Sound } \\
\text { Class }\end{array}$ & $\begin{array}{l}\text { Max. } \\
\text { Mounting } \\
\text { Height } \\
\text { f.) } \Delta\end{array}$ & $\begin{array}{l}\text { *Heat } \\
\text { Throw or } \\
\text { Spread } \\
\text { (ft.) }\end{array}$ & tCfm. & $\begin{array}{l}\text { Outlet } \\
\text { Velocity } \\
(\text { Fpm })\end{array}$ & $\begin{array}{c}\text { Final } \\
\text { Air } \\
\text { Temp. } \\
\text { (F) }\end{array}$ & $\begin{array}{l}\text { Conden- } \\
\text { sate } \\
\text { Lbs.hr. }\end{array}$ & $H p$ & $\begin{array}{l}\text { Approx. } \\
\text { Rpm. }\end{array}$ \\
\hline 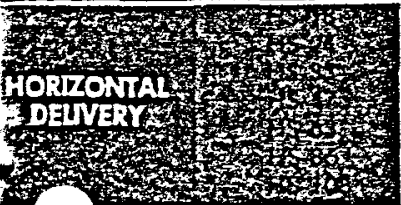 & $\begin{array}{r}14,000 \\
18,000 \\
25,000 \\
38,000 \\
47,000 \\
64,000 \\
81,000\end{array}$ & $\begin{array}{r}58 \\
75 \\
104 \\
158 \\
195 \\
265 \\
340\end{array}$ & $\begin{array}{l}\text { II } \\
11 \\
\text { III } \\
\text { III } \\
\text { III }\end{array}$ & $\begin{array}{l}8 \\
9 \\
10 \\
12 \\
14 \\
15 \\
17\end{array}$ & $\begin{array}{l}10 \\
11 \\
13 \\
17 \\
17 \\
19 \\
19\end{array}$ & $\begin{array}{l}220 \\
230 \\
395 \\
450 \\
685 \\
825 \\
1,255\end{array}$ & $\begin{array}{l}415 \\
440 \\
440 \\
515 \\
430 \\
525 \\
500\end{array}$ & $\begin{array}{l}118 \\
131 \\
118 \\
137 \\
122 \\
131 \\
119\end{array}$ & $\begin{array}{l}14 \\
18 \\
26 \\
36 \\
49 \\
66 \\
84\end{array}$ & $\begin{array}{c}16 M H P \\
1 / 25 \\
1 / 25 \\
1 / 12 \\
1 / 12 \\
1 / 6 \\
1 / 6\end{array}$ & $\begin{array}{l}1000 \\
1000 \\
1000 \\
1000 \\
1000 \\
1000 \\
1000\end{array}$ \\
\hline
\end{tabular}

-Hd hital units with horizontal louvers opened $30^{\circ}$ from the vertical plane.

Vertical types equipped with cone jet deflector, blodes in full open position.

*For most popular motor used on these models.

tCfm for horizontal types is entering Cfm.

Cfm for vertical and "power-throw" types is leaving Cfm.

IHigh motor speed. 


\section{hot water unit heater selection data - continued}

\section{table 11 - hot water heating capacity conversion factors}

To determine the heating capacity Btu/hr) of a unit heater at any entering water temperature and entering air temperature multiply the capacity at $200^{\circ} \mathrm{F} \mathrm{E.} \mathrm{W.T.} \mathrm{and} 60^{\circ} \mathrm{F} \mathrm{E.A.T.} \mathrm{by} \mathrm{the} \mathrm{factor}$ from this table. Note: GPM must be identical to that at $200^{\circ} \mathrm{F}$ E.W.T. and $60^{\circ} \mathrm{F}$ E.A.T.

\begin{tabular}{|c|c|c|c|c|c|c|c|c|c|c|c|}
\hline 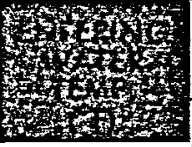 & $\frac{7 x}{x+1}$ & $\frac{1}{46 x}$ & $4 x$ & $\frac{17}{3 \times 2}$ & 5 & 4250 & $\frac{16}{34}$ & $\frac{1}{47}$ & 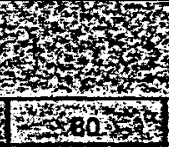 & 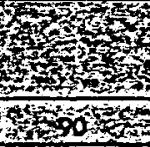 & $300 \%$ \\
\hline 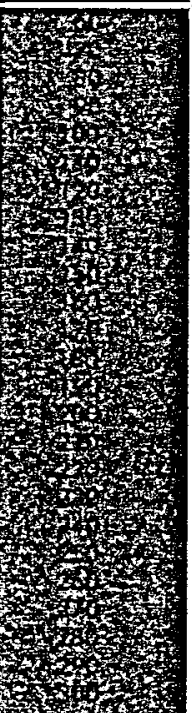 & $\begin{array}{l}0.462 \\
0.539 \\
0.615 \\
0.692 \\
0.769 \\
0.846 \\
0.923 \\
1.000 \\
1.077 \\
1.154 \\
1.231 \\
1.308 \\
1.385 \\
1.462 \\
1.539 \\
1.615 \\
1.692 \\
1.769 \\
1.846 \\
1.923 \\
2.000 \\
2.077 \\
2.154 \\
2.231 \\
2.308\end{array}$ & $\begin{array}{l}0.380 \\
0.456 \\
0.531 \\
0.607 \\
0.683 \\
0.759 \\
0.835 \\
0.911 \\
0.987 \\
1.063 \\
1.139 \\
1.215 \\
1.291 \\
1.367 \\
1.443 \\
1.519 \\
1.594 \\
1.670 \\
1.746 \\
1.822 \\
1.898 \\
1.974 \\
2.050 \\
2.126 \\
2.202\end{array}$ & $\begin{array}{l}0.300 \\
0.375 \\
0.450 \\
0.524 \\
0.599 \\
0.674 \\
0.749 \\
0.824 \\
0.899 \\
0.974 \\
1.049 \\
1.124 \\
1.199 \\
1.274 \\
1.349 \\
1.424 \\
1.499 \\
1.573 \\
1.649 \\
1.723 \\
1.798 \\
1.873 \\
1.948 \\
2.023 \\
2.098\end{array}$ & $\begin{array}{l}0.222 \\
0.296 \\
0.370 \\
0.444 \\
0.518 \\
0.592 \\
0.666 \\
0.740 \\
0.814 \\
0.888 \\
0.962 \\
1.036 \\
1.110 \\
1.184 \\
1.258 \\
1.332 \\
1.406 \\
1.480 \\
1.554 \\
1.628 \\
1.702 \\
1.776 \\
1.850 \\
1.924 \\
1.998\end{array}$ & $\begin{array}{l}0.146 \\
0.219 \\
0.293 \\
0.366 \\
0.439 \\
0.512 \\
0.585 \\
0.658 \\
0.731 \\
0.805 \\
0.878 \\
0.950 \\
1.024 \\
1.097 \\
1.170 \\
1.243 \\
1.312 \\
1.390 \\
1.463 \\
1.536 \\
1.609 \\
1.682 \\
1.755 \\
1.829 \\
1.902\end{array}$ & $\begin{array}{l}0.072 \\
0.145 \\
0.217 \\
0.289 \\
0.361 \\
0.434 \\
0.506 \\
0.578 \\
0.651 \\
0.723 \\
0.795 \\
0.867 \\
0.940 \\
1.012 \\
1.084 \\
1.157 \\
1.229 \\
1.301 \\
1.373 \\
1.446 \\
1.518 \\
1.590 \\
1.663 \\
1.734 \\
1.807\end{array}$ & $\begin{array}{l}0 \\
0 \\
.071 \\
0.143 \\
0.214 \\
0.286 \\
0.357 \\
0.429 \\
0.500 \\
0.571 \\
0.643 \\
0.714 \\
0.786 \\
0.857 \\
0.929 \\
1.000 \\
1.071 \\
1.143 \\
1.214 \\
1.286 \\
1.357 \\
1.429 \\
1.500 \\
1.571 \\
1.643 \\
1.714\end{array}$ & $\begin{array}{l}0 \\
0 \\
0 \\
0.071 \\
0.141 \\
0.212 \\
0.283 \\
0.353 \\
0.424 \\
0.494 \\
0.565 \\
0.636 \\
0.706 \\
0.777 \\
0.848 \\
0.918 \\
0.989 \\
1.060 \\
1.130 \\
1.201 \\
1.272 \\
1.342 \\
1.413 \\
1.483 \\
1.554 \\
1.625\end{array}$ & $\begin{array}{c}0 \\
0 \\
0 \\
0.070 \\
0.140 \\
0.210 \\
0.279 \\
0.349 \\
0.419 \\
0.489 \\
0.559 \\
0.629 \\
0.699 \\
0.768 \\
0.838 \\
0.908 \\
0.978 \\
1.048 \\
1.118 \\
1.188 \\
1.257 \\
1.327 \\
1.397 \\
1.467 \\
1.537\end{array}$ & $\begin{array}{l}0 \\
0 \\
0 \\
0 \\
0.069 \\
0.138 \\
0.207 \\
0.276 \\
0.345 \\
0.414 \\
0.483 \\
0.552 \\
0.621 \\
0.690 \\
0.759 \\
0.828 \\
0.897 \\
0.966 \\
1.035 \\
1.104 \\
1.173 \\
1.242 \\
1.311 \\
1.380 \\
1.449\end{array}$ & $\begin{array}{c}0 \\
0 \\
0 \\
0 \\
0 \\
0.068 \\
0.137 \\
0.205 \\
0.273 \\
0.342 \\
0.410 \\
0.478 \\
0.547 \\
0.615 \\
0.684 \\
0.752 \\
0.820 \\
0.889 \\
0.957 \\
1.025 \\
1.094 \\
1.162 \\
1.230 \\
1.300 \\
1.367\end{array}$ \\
\hline
\end{tabular}

Conversion factors in table II may be used with standard hot water data on page 18 or 19, or with data obtained from the standard hot water performance curves.

table 12 - minimum water flow and water volume (gallons)

\begin{tabular}{|c|c|c|c|c|c|c|c|c|}
\hline 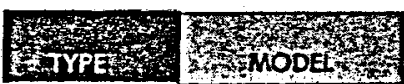 & spM & OLUME & WTPE & MiNM & youlus & 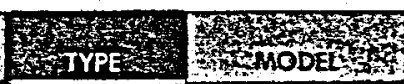 & MNN & $\begin{array}{l}\text { Cogl } \\
\text { YOWME } \\
\text { TALS. }\end{array}$ \\
\hline 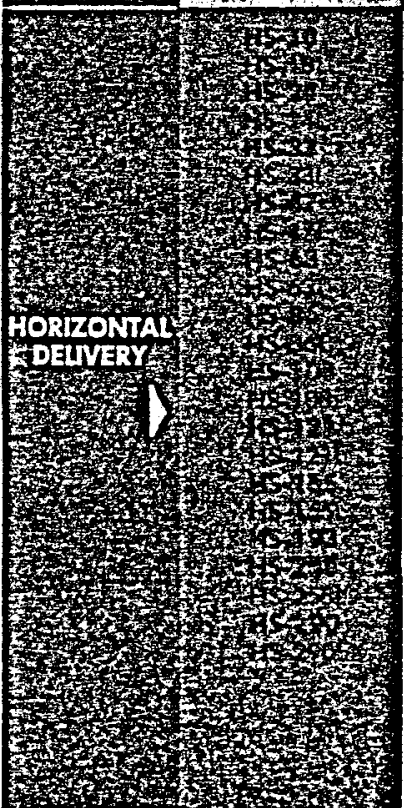 & $\begin{array}{l}15 \\
15 \\
15 \\
15 \\
20 \\
.20 \\
20 \\
.20 \\
.20 \\
.20 \\
.20 \\
.20 \\
.20 \\
.20 \\
.20 \\
.20 \\
.20 \\
.40 \\
.40 \\
.40 \\
.40 \\
.40\end{array}$ & $\begin{array}{c}13 \\
13 \\
.13 \\
13 \\
13 \\
41 \\
41 \\
.41 \\
411 \\
66 \\
66 \\
68 \\
.66 \\
.98 \\
.98 \\
.98 \\
.98 \\
1.35 \\
1.35 \\
1.45 \\
2.2 \\
2.2 \\
2.2 \\
2.2\end{array}$ & 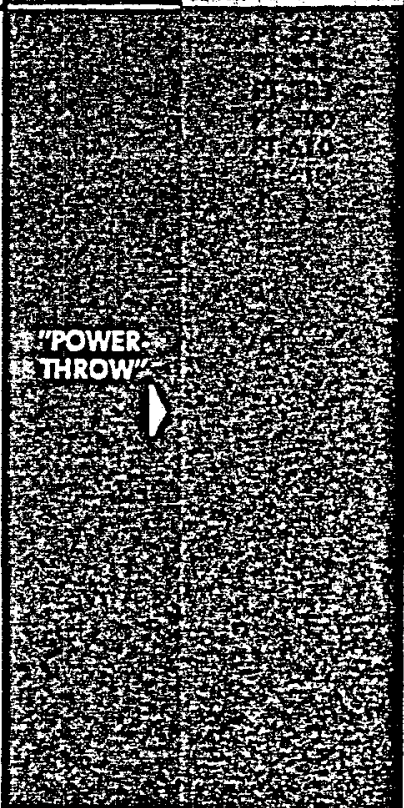 & $\begin{array}{l}2.7 \\
2.7 \\
2.7 \\
3.6 \\
3.6 \\
3.6\end{array}$ & $\begin{array}{l}.97 \\
1.24 \\
1.24 \\
1.66 \\
1.98 \\
1.98\end{array}$ & \begin{tabular}{|ll} 
\\
\end{tabular} & $\begin{array}{l}.30 \\
.30 \\
.45 \\
.45 \\
.00 \\
.00 \\
.75 \\
.75 \\
.00 \\
.00 \\
.75 \\
.95 \\
.90 \\
1.20 \\
1.20 \\
1.20 \\
1.20 \\
1.35 \\
1.35 \\
1.35 \\
1.35 \\
1.35 \\
1.8 \\
1.8 \\
3.6 \\
3.6\end{array}$ & $\begin{array}{l}.15 \\
.15 \\
.23 \\
.23 \\
.31 \\
.31 \\
.38 \\
.38 \\
.43 \\
.43 \\
.54 \\
.54 \\
.65 \\
.65 \\
.86 \\
.86 \\
.86 \\
.86 \\
.97 \\
.97 \\
1.24 \\
1.24 \\
1.24 \\
1.24 \\
1.66 \\
1.66 \\
1.98 \\
1.98\end{array}$ \\
\hline
\end{tabular}


